\title{
Additions to the genus Gimesia: description of Gimesia alba sp. nov., Gimesia algae sp. nov., Gimesia aquarii sp. nov., Gimesia aquatilis sp. nov., Gimesia fumaroli sp. nov. and Gimesia panareensis sp. nov., isolated from aquatic habitats of the Northern Hemisphere
}

\author{
Sandra Wiegand • Mareike Jogler • Christian Boedeker • Anja Heuer • \\ Patrick Rast • Stijn H. Peeters • Mike S. M. Jetten • Anne-Kristin Kaster • \\ Manfred Rohde $\cdot$ Nicolai Kallscheuer $\cdot$ Christian Jogler $\mathbb{C}$
}

Received: 2 July 2020/Accepted: 19 October 2020/Published online: 24 November 2020

(C) The Author(s) 2020

\begin{abstract}
Thirteen novel planctomycetal strains were isolated from five different aquatic sampling locations. These comprise the hydrothermal vent system close to Panarea Island (Italy), a biofilm on the surface of kelp at Monterey Bay (CA, USA), sediment and algae on Mallorca Island (Spain) and Helgoland Island (Germany), as well as a seawater aquarium in Braunschweig, Germany. All strains were shown to belong to the genus Gimesia. Their genomes cover a size range from 7.22 to $8.29 \mathrm{Mb}$ and have a $\mathrm{G}+\mathrm{C}$ content between 45.1 and $53.7 \%$. All strains are mesophilic $\left(\mathrm{T}_{\mathrm{opt}} 26-33{ }^{\circ} \mathrm{C}\right)$ with generation times between 12 and $32 \mathrm{~h}$. Analysis of fatty acids yielded palmitic acid (16:0) and a fatty acid with the
\end{abstract}

Electronic supplementary material The online version of this article (https://doi.org/10.1007/s10482-020-01489-0) contains supplementary material, which is available to authorized users.

\footnotetext{
S. Wiegand · A.-K. Kaster

Institute for Biological Interfaces 5, Karlsruhe Institute of

Technology, Eggenstein-Leopoldshafen, Germany

M. Jogler · C. Jogler ( $\square)$

Department of Microbial Interactions, Friedrich-Schiller-

University, Jena, Germany

e-mail: christian.jogler@uni-jena.de

C. Boedeker · A. Heuer · P. Rast

Leibniz Institute DSMZ, Brunswick, Germany
}

equivalent chain length of 15.817 as major compounds. While five of the novel strains belong to the already described species Gimesia maris and Gimesia chilikensis, the other strains belong to novel species, for which we propose the names Gimesia alba (type strain $\operatorname{Pan} 241 \mathrm{w}^{\mathrm{T}}=\mathrm{DSM} 100744^{\mathrm{T}}=\mathrm{LMG}$ $31345^{\mathrm{T}}=$ CECT $9841^{\mathrm{T}}=$ VKM B-3430 ${ }^{\mathrm{T}}$ ), Gimesia algae (type strain $\operatorname{Pan} 161^{\mathrm{T}}=\mathrm{CECT} 30192^{\mathrm{T}}=$ STH00943 ${ }^{\mathrm{T}}=$ LMG $29130^{\mathrm{T}}$ ), Gimesia aquarii (type strain $\mathrm{V} 144^{\mathrm{T}}=\mathrm{DSM} 101710^{\mathrm{T}}=\mathrm{VKM} \quad \mathrm{B}-3433^{\mathrm{T}}$ ), Gimesia fumaroli (type strain $\mathrm{Enr} 17^{\mathrm{T}}=\mathrm{DSM}$ $100710^{\mathrm{T}}=$ VKM B-3429 ${ }^{\mathrm{T}}$ ) and Gimesia panareensis (type strain Enr10 ${ }^{\mathrm{T}}=\mathrm{DSM} \quad 100416^{\mathrm{T}}=\mathrm{LMG}$ $29082^{\mathrm{T}}$ ). STH numbers refer to the Jena Microbial Resource Collection (JMRC).

Keywords Planctomycetes - Marine bacteria . Planctomycetaceae $\cdot$ Budding $\cdot$ Crateriform structures $\cdot$ Stalk $\cdot$ Gimesia maris
S. H. Peeters · M. S. M. Jetten · N. Kallscheuer
C. Jogler
Department of Microbiology, Radboud University,
Nijmegen, The Netherlands
M. Rohde
Central Facility for Microscopy, Helmholtz Centre for Infection Research, Brunswick, Germany




\section{Introduction}

The bacterial phylum Planctomycetes is part of the PVC superphylum (together with the phyla Chlamydiae, Verrucomicrobia and other sister phyla) (Wagner and Horn 2006). According to current taxonomy, the phylum Planctomycetes features the classes Planctomycetia, Phycisphaerae and Candidatus Brocadiae. Members of the class Planctomycetia in particular occur ubiquitously, but predominantly in aquatic environments (Wiegand et al. 2018). They have been found on various algal surfaces (Bengtsson et al. 2012; Bondoso et al. 2014, 2015, 2017; Lage and Bondoso 2014; Vollmers et al. 2017), on which they can dominate biofilms (Bengtsson and Øvreås 2010; Wiegand et al. 2018). Their metabolic ability to degrade complex carbon substrates (Jeske et al. 2013; Lachnit et al. 2013) makes them important players in global carbon cycling (Wiegand et al. 2018). Planctomycetes are suspected to produce small bioactive molecules (Graça et al. 2016; Jeske et al. 2016; Wiegand et al. 2020). Recently, small molecules belonging to the class of $N$-acyl amino acids have been elucidated from Planctomycetes and were shown to be involved in the modulation of biofilm community compositions (Kallscheuer et al. 2020a). This finding might lead to an explanation why Planctomycetes can dominate algal surfaces without being outcompeted, despite their notoriously slow growth (Wiegand et al. 2018).

Members of the class Planctomycetia divide by budding, without employing the canonical divisome proteins, including the otherwise universal FtsZ (Jogler et al. 2012; Pilhofer et al. 2008; Wiegand et al. 2020). Most strains seem to have a biphasic lifestyle, alternating between planktonic swimmer cells and sessile mother cells (Wiegand et al. 2020). Their periplasm can be extremely enlarged and compartmentalised (Acehan et al. 2013; Boedeker et al. 2017), conceivably for the digestion of internalised polysaccharides (Boedeker et al. 2017). Interestingly, Planctomycetes were only recently found to possess a peptidoglycan cell wall (Jeske et al. 2015; van Teeseling et al. 2015), as have members of the closely related phylum Verrucomicrobia (Rast et al. 2017).

The class Planctomycetia has recently been taxonomically restructured and now contains four different orders: Gemmatales, Isosphaerales, Pirellulales and the revised Planctomycetales (Dedysh et al. 2020b). The latter taxon harbours only a single family, the Planctomycetaceae, which contains the oldest descriptions of planctomycetal bacteria. The namelending but lost Planctomyces bekefii was the first described strain of the phylum (Gimesi 1924) and has recently been re-identified and described (Dedysh et al. 2020a). The first described axenic culture of the family was 'Planctomyces maris' (Bauld and Staley 1976), which was later transferred to Gimesia maris (Scheuner et al. 2014). Cells of this species have a long stalk on the non-reproductive pole of the mother cell, whereas daughter cells have a single subpolar flagellum (Scheuner et al. 2014). While these features were also found in the recently described species Gimesia benthica (Wang et al. 2020), they were however not identified in another recently described species of the genus, Gimesia chilikensis (Kumar et al. 2020). While many Planctomycetes produce carotenoids as pigmenting compounds, probably for protection against UV radiation or oxidative stress (Kallscheuer et al. 2019), the three previously described Gimesia species possess a white colony colour (Kumar et al. 2020), indicating the inability to produce such pigments.

In this study, we aimed to broaden the current collection of Gimesia strains by the description and detailed comparison of morphological, physiological and phylogenetic properties of thirteen isolates whose genomes have been published before and whose species names have already been suggested based on preliminary analyses (Wiegand et al. 2020). We verify the earlier phylogenetic placement and show that the strains belong to two known species and five hitherto undescribed Gimesia species.

\section{Materials and methods}

Cultivation conditions and isolation

For strain isolation and cultivation, M1H NAG ASW medium was used. For medium preparation $0.25 \mathrm{~g}$ peptone (Bacto), $0.25 \mathrm{~g}$ yeast extract (Bacto), $2.38 \mathrm{~g}$ (4-(2-hydroxyethyl)-1-piperazineethane-sulfonic acid) (HEPES) (10 mM), $250 \mathrm{~mL}$ artificial seawater (ASW) and $20 \mathrm{~mL}$ Hutner's basal salt solution were mixed in a final volume of $973 \mathrm{~mL}$ double distilled water. The $\mathrm{pH}$ was adjusted to 7.5 using $5 \mathrm{M} \mathrm{KOH}$ and the solution was autoclaved for $20 \mathrm{~min}$ at $121{ }^{\circ} \mathrm{C}$. After 
cooling, the following solutions were added aseptically: $1 \mathrm{~mL}$ of $25 \%(\mathrm{w} / \mathrm{v})$ glucose, $5 \mathrm{~mL}$ vitamin solution, $1 \mathrm{~mL}$ trace element solution and $20 \mathrm{~mL}$ of a stock solution with $50 \mathrm{~g} / \mathrm{L} N$-acetyl glucosamine (NAG). ASW contained $46.94 \mathrm{~g} / \mathrm{L} \mathrm{NaCl}, 7.84 \mathrm{~g} / \mathrm{L}$ $\mathrm{Na}_{2} \mathrm{SO}_{4}, 21.28 \mathrm{~g} / \mathrm{L} \mathrm{MgCl}_{2} \times 6 \mathrm{H}_{2} \mathrm{O}, 2.86 \mathrm{~g} / \mathrm{L} \mathrm{CaCl}_{2}$ $\times 2 \mathrm{H}_{2} \mathrm{O}, \quad 0.384 \mathrm{~g} / \mathrm{L} \quad \mathrm{NaHCO}_{3}, \quad 1.384 \mathrm{~g} / \mathrm{L} \quad \mathrm{KCl}$, $0.192 \mathrm{~g} / \mathrm{L} \mathrm{KBr}, 0.052 \mathrm{~g} / \mathrm{L} \mathrm{H}_{3} \mathrm{BO}_{3}, 0.08 \mathrm{~g} / \mathrm{L} \quad \mathrm{SrCl}_{2}$ $\times 6 \mathrm{H}_{2} \mathrm{O}$ and $0.006 \mathrm{~g} / \mathrm{L} \mathrm{NaF}$ and was freshly prepared before addition to the base solution. Hutner's basal salt solution was prepared by first dissolving $10 \mathrm{~g}$ nitrilotriacetic acid in $700 \mathrm{~mL}$ double distilled water and adjusting the $\mathrm{pH}$ to 7.2 using $5 \mathrm{M} \mathrm{KOH}$. Subsequently, the following compounds were added: $29.7 \mathrm{~g} \mathrm{MgSO}_{4}$ $\times 7 \mathrm{H}_{2} \mathrm{O}, 3.34 \mathrm{~g} \mathrm{CaCl}_{2} \times 2 \mathrm{H}_{2} \mathrm{O}, 0.01267 \mathrm{~g} \mathrm{Na}_{2} \mathrm{MoO}_{4}$ $\times 2 \mathrm{H}_{2} \mathrm{O}, 0.099 \mathrm{~g} \mathrm{FeSO}_{4} \times 7 \mathrm{H}_{2} \mathrm{O}$ and $50 \mathrm{~mL}$ metal salt solution 44 . The solution was filled up to $1 \mathrm{~L}$, sterilised by filtering and stored at $4{ }^{\circ} \mathrm{C}$. Metal salt solution 44 consisted of $250 \mathrm{mg} / \mathrm{L} \mathrm{Na}_{2}$-EDTA, $1095 \mathrm{mg} / \mathrm{L} \quad \mathrm{ZnSO}_{4} \times 7 \mathrm{H}_{2} \mathrm{O}, \quad 500 \mathrm{mg} / \mathrm{L} \quad \mathrm{FeSO}_{4} \times$ $7 \mathrm{H}_{2} \mathrm{O}, 154 \mathrm{mg} / \mathrm{L} \mathrm{MnSO}_{4} \times \mathrm{H}_{2} \mathrm{O}, 39.5 \mathrm{mg} / \mathrm{L} \mathrm{CuSO}_{4}$ $\times 5 \mathrm{H}_{2} \mathrm{O}, 20.3 \mathrm{mg} / \mathrm{L} \mathrm{CoCl} 2 \times 6 \mathrm{H}_{2} \mathrm{O}$ and $17.7 \mathrm{mg} / \mathrm{L}$ $\mathrm{Na}_{2} \mathrm{~B}_{4} \mathrm{O}_{7} \times 10 \mathrm{H}_{2} \mathrm{O}$. In the first step, EDTA was dissolved and, if required, a few drops of concentrated $\mathrm{H}_{2} \mathrm{SO}_{4}$ were added to retard precipitation of the heavy metal ions. Metal salt solution 44 was sterilised by filtration and stored at $4{ }^{\circ} \mathrm{C}$. Vitamin solution contained per litre: $10 \mathrm{mg} p$-aminobenzoic acid, $4 \mathrm{mg}$ biotin, $20 \mathrm{mg}$ pyridoxine hydrochloride, $10 \mathrm{mg}$ thiamine hydrochloride, $10 \mathrm{mg}$ Ca-pantothenate, $4 \mathrm{mg}$ folic acid, $10 \mathrm{mg}$ riboflavin, $10 \mathrm{mg}$ nicotinamide and $0.2 \mathrm{mg}$ vitamin $\mathrm{B}_{12}$. $p$-Aminobenzoic acid was dissolved first and the solution was sterilised by filtration and stored in the dark at $4{ }^{\circ} \mathrm{C}$. The trace element solution, containing $1.5 \mathrm{~g} / \mathrm{L}$ Na-nitrilotriacetate, $500 \mathrm{mg} / \mathrm{L} \mathrm{MnSO}_{4} \times \mathrm{H}_{2} \mathrm{O}, 100 \mathrm{mg} / \mathrm{LFeSO}_{4} \times 7 \mathrm{H}_{2} \mathrm{O}$, $100 \mathrm{mg} / \mathrm{L} \quad \mathrm{Co}\left(\mathrm{NO}_{3}\right)_{2} \times 6 \mathrm{H}_{2} \mathrm{O}, \quad 100 \mathrm{mg} / \mathrm{L} \quad \mathrm{ZnCl}_{2}$, $50 \mathrm{mg} / \mathrm{L} \mathrm{NiCl} \mathrm{N}_{2} \times 6 \mathrm{H}_{2} \mathrm{O}, 50 \mathrm{mg} / \mathrm{L} \mathrm{H}_{2} \mathrm{SeO}_{3}, 10 \mathrm{mg} / \mathrm{L}$ $\mathrm{CuSO}_{4} \times 5 \mathrm{H}_{2} \mathrm{O}, \quad 10 \mathrm{mg} / \mathrm{L} \quad \mathrm{AlK}\left(\mathrm{SO}_{4}\right)_{2} \times 12 \mathrm{H}_{2} \mathrm{O}$, $10 \mathrm{mg} / \mathrm{L} \quad \mathrm{H}_{3} \mathrm{BO}_{3}, 10 \mathrm{mg} / \mathrm{L} \quad \mathrm{NaMoO}_{4} \times 2 \mathrm{H}_{2} \mathrm{O}$ and $10 \mathrm{mg} / \mathrm{L} \mathrm{Na}_{2} \mathrm{WO}_{4} \times 2 \mathrm{H}_{2} \mathrm{O}$, was sterilised by filtration and stored in the dark at $4{ }^{\circ} \mathrm{C}$.

The sampling location and collected material for isolation of the strains described here are listed in Table S1. Colonies obtained from the initial cultivation step on M1H NAG ASW plates solidified with agar or gellan gum were re-streaked on a new plate and maintained in liquid M1H NAG ASW medium. Initial amplification and sequencing of the 16S rRNA gene was performed as previously described (Rast et al. 2017). This step was included to check whether the strains obtained are members of the phylum Planctomycetes.

\section{Light microscopy}

Phase contrast (Phaco) analyses were performed employing a Nikon Eclipse Ti inverted microscope with a Nikon DS-Ri2 camera (blue LED). Specimens were immobilised in MatTek glass bottom dishes (35 mm, No. 1.5) employing a 1\% (w/v) agarose cushion (Will et al. 2018). Images were analysed using the Nikon NIS-Elements software (version 4.3). To determine the cell size, at least 100 representative cells were counted manually (Annotations and Measurements, NIS-Elements Imaging Software, Nikon Instruments Europe) or by using the NIS-Elements semi-automated object count tool (smooth: $4 \times$, clean: $4 \times$, fill holes: on, separate: $4 \times$ ). The Object Count tool enables setting a threshold for the image, automatically measures the binary objects and exports the measured data to a file.

\section{Electron microscopy}

For field emission scanning electron microscopy, bacteria were fixed in $1 \%(\mathrm{v} / \mathrm{v})$ formaldehyde in HEPES buffer (3 mM HEPES, $0.3 \mathrm{mM} \mathrm{CaCl}_{2}$, $0.3 \mathrm{mM} \mathrm{MgCl}_{2}, 2.7 \mathrm{mM}$ sucrose, $\mathrm{pH}$ 6.9) for $1 \mathrm{~h}$ on ice and washed once employing the same buffer (Rast et al. 2017). Cover slips with a diameter of $12 \mathrm{~mm}$ were coated with a poly-L-lysine solution (SigmaAldrich) for $10 \mathrm{~min}$, washed in distilled water and airdried. $50 \mu \mathrm{L}$ of the fixed bacterial solution was placed on a cover slip and allowed to settle for $10 \mathrm{~min}$. Cover slips were then fixed in $1 \%$ (v/v) glutaraldehyde in TE buffer (20 mM TRIS, 1 mM EDTA, pH 6.9) for $5 \mathrm{~min}$ at room temperature and subsequently washed twice with TE buffer before dehydrating in a graded series of acetone $(10,30,50,70,90,100 \%(\mathrm{v} / \mathrm{v}))$ on ice for $10 \mathrm{~min}$ at each concentration. Samples from the $100 \%$ acetone step were brought to room temperature before placing them in fresh $100 \%$ acetone. Samples were then subjected to critical-point drying with liquid $\mathrm{CO}_{2}$ (CPD 300, Leica). Dried samples were covered with a gold/palladium (80/20) film by sputter coating (SCD 500, Bal-Tec) before examination in a field emission scanning electron microscope (Zeiss Merlin) using the 
Everhart-Thornley HESE2 detector and the inlens SE detector in a 25:75 ratio at an acceleration voltage of $5 \mathrm{kV}$.

Physiological analyses

For determination of the temperature optimum for growth, all strains were cultivated in M1H NAG ASW medium at $\mathrm{pH}$ 7.5. For determination of the $\mathrm{pH}$ optimum for growth, $100 \mathrm{mM}$ HEPES was used instead of $10 \mathrm{mM}$ for cultivations at $\mathrm{pH} 7.0,7.5$ and 8.0. For cultivation at $\mathrm{pH}$ 5.0-6.0 HEPES was replaced by $100 \mathrm{mM}$ 2-( $N$-morpholino)ethanesulfonic acid (MES), whereas $100 \mathrm{mM} \mathrm{N}$-cyclohexyl-2aminoethanesulfonic acid (CHES) served as a buffering agent at $\mathrm{pH}$ 9.0-10.0. Cultivations for determination of the $\mathrm{pH}$ optimum were performed at $28{ }^{\circ} \mathrm{C}$. For determination of the temperature optimum, all strains were cultivated at $\mathrm{pH} 8.0$ at different temperatures ranging from 10 to $40{ }^{\circ} \mathrm{C}$.

Cellular fatty acid analysis

Biomass of all tested strains was obtained from liquid cultures grown in M1H NAG ASW medium under optimal growth conditions until cells reached the stationary phase. $30 \mathrm{mg}$ of lyophilised biomass was analysed by the Identification Service of the German Collection of Microorganisms and Cell Cultures (DSMZ) according to standard protocols (Kämpfer and Kroppenstedt 1996; Kuykendall et al. 1988; Miller 1982).

Phylogenetic analyses

The genomes of all strains were published previously (Wiegand et al. 2020) and are available from RefSeq under accession numbers NZ_CP036269.1, NZ_CP036343.1, NZ_CP037920.1, NZ_CP037422.1, NZ_CP036266.1, NZ_CP036342.1, NZ_CP036347.1, NZ_CP037452.1, NZ_CP036353.1, NZ_CP036341.1, NZ_CP037421.1, NZ_CP036277.1 and NZ_CP03 6317.1. The GenBank accession numbers of the respective 16S rRNA genes are MK554516, MK554515, MK554556, MK554536, MK554525, MK554514, MK554557, MK554524, MK559968, MK554512, MK554508, MK559981 and MK554531. 16S rRNA gene sequence-based phylogeny was computed for the strains described here and the type strains of reference species. The analysis also included strains described in the last year (Boersma et al. 2019; Dedysh et al. 2020a; Kallscheuer et al. 2020b; Kohn et al. 2016, 2019, 2020; Kumar et al. 2020; Peeters et al. 2020; Rivas-Marin et al. 2020a, b; Vitorino et al. 2020) and strains recently published, but not yet described (Wiegand et al. 2020). The 16S rRNA gene sequences were aligned with SINA (Pruesse et al. 2012). The phylogenetic analysis was performed employing a maximum likelihood approach with 1000 bootstraps, the nucleotide substitution model GTR, gamma distribution and estimation of proportion of invariable sites (GTRGAMMAI option) (Stamatakis 2014). Three 16S rRNA genes of bacterial strains from the PVC superphylum (outside of the phylum Planctomycetes) served as outgroup. The rpoB nucleotide sequences (encoding the RNA polymerase $\beta$-subunit) were taken from publicly available genome annotations and the sequence identities were determined as previously described (Bondoso et al. 2013) with Clustal Omega (Sievers et al. 2011). Alignment and matrix calculation were performed upon extracting only those parts of the sequence that would have been sequenced with the primer set described by Bondoso et al. (2013).

The average nucleotide identity (ANI) was calculated using OrthoANI (Lee et al. 2016). The average amino acid identity (AAI) was obtained using the aai.rb script of the enveomics collection (Rodriguez-R and Konstantinidis 2016) and the percentage of conserved proteins (POCP) was calculated as described before (Qin et al. 2014).

For the multilocus sequence analysis (MLSA), the unique single-copy core genome of all analysed genomes was determined with proteinortho5 (Lechner et al. 2011) with the 'selfblast' option enabled. The protein sequences of the resulting orthologous groups were aligned using MUSCLE v.3.8.31 (Edgar 2004). After clipping, partially aligned $C$ - and $N$-terminal regions and poorly aligned internal regions were filtered using Gblocks (Castresana 2000). The final alignment of 900 ubiquitous genes with a combined length of 440,140 conserved amino acid residues was concatenated and clustered using FastTree (Price et al. 2010). The outgroup consisted of three genomes from strains of the family Pirellulaceae. 
Genomic analysis

The genome-based analysis of enzymes participating in primary metabolism was performed by examining locally computed InterProScan (Mitchell et al. 2019) results cross-referenced with information from the UniProt (UniProt 2019) database and BLASTp results of 'typical' protein sequences. The local alignment of the genomes was computed with BLASTn and visualised with Easyfig (Sullivan et al. 2011). The analysis of the pan genomes was performed with anvi'o (Eren et al. 2015), following the pangenomics workflow (Delmont and Eren 2018). The origin of genes of primary metabolism was tested by querying the BLAST nr database with the gained genes from the novel strains (maximal target sequences: 250), concatenation and deduplication of the results, subsequent alignment by MUSCLE (Edgar 2004), tree generation with FastTree 2 (Price et al. 2010) and visualisation with iTOL v4 (Letunic and Bork 2019).

\section{Results and discussion}

Isolation of the strains

Strains CA11, Mal35, Pan161 ${ }^{\mathrm{T}}$, Pan241w ${ }^{\mathrm{T}}, \mathrm{Enr} 17^{\mathrm{T}}$, V202, V144 ${ }^{\mathrm{T}}$, MalM14, HG66A1, V6, Pan110, Enr10 $0^{\mathrm{T}}$ and Pan153 were previously reported (Wiegand et al. 2020) as novel isolates gained during a large diversity-driven cultivation approach targeting the phylum Planctomycetes. The 13 strains were isolated from sediments or biofilms from five different aquatic sampling locations: the Monterey Bay kelp forest (CA11), the hydrothermal vent system offshore of Panarea Island (Enr10 ${ }^{\mathrm{T}}$, Enr17 $7^{\mathrm{T}}$, Pan 110, Pan 153, Pan $\left.161^{\mathrm{T}}, \operatorname{Pan} 241 \mathrm{w}^{\mathrm{T}}\right)$, a public beach at Mallorca Island (Mal35, MalM14), rocky tideland at Helgoland Island (HG66A1) and a seawater ornamental fish tank (V6, V144 $\left.{ }^{\mathrm{T}}, \mathrm{V} 202\right)$. More details are provided in Table S1.

\section{Phylogenetic inference}

When reviewing 16S rRNA gene sequence-, as well as MLSA-based phylogeny, it was evident that all strains are close neighbours of G. maris 534-30 ${ }^{\mathrm{T}}$ (Bauld and Staley 1976; Scheuner et al. 2014), the type strain of the type species of the genus Gimesia, and the recently described G. chilikensis $\mathrm{JC} 646^{\mathrm{T}}$ (Kumar et al. 2020) and G. benthica E7 (Wang et al. 2020) (Fig. 1). By closer examination of the phylogenetic trees, the strains can be subdivided into seven groups: (I) $G$. maris 534-30 ${ }^{\mathrm{T}}$, CA11, Mal35; (II) Pan $161^{\mathrm{T}}$; (III) V202, V144 ${ }^{\mathrm{T}}$; (IV) Pan241w ${ }^{\mathrm{T}}$; (V) Enr17 ${ }^{\mathrm{T}}$; (VI) $G$. chilikensis $\mathrm{JC} 46^{\mathrm{T}}$, G. benthica E7, MalM14, HG66A1, V6; and (VII) Pan110, Enr10 ${ }^{\mathrm{T}}$ and Pan153. Interestingly, the geographic origin of the strains is not closely reflected in these groups; while groups V and VII only comprise strains from one location, in groups I and VI each strain is derived from a different sampling spot.

The assessment of the seven groups all belonging to the genus Gimesia is confirmed by average amino identities (AAI) and the percentage of conserved proteins (POCP): all values are notably above the genus thresholds of 60-80\% (Luo et al. 2014) and 50\% (Qin et al. 2014), respectively (Fig. 2 and Table S2).

When applying the proposed ANI threshold of 95\% for delineation of species (Kim et al. 2014), the seven introduced groups each form a separate species. While all determined values within the groups are higher than $95 \%$, all values between the groups are below $95 \%$ (Fig. 2 and Table S2). The same picture emerges for the comparison of $r p o B$ gene identities. The species threshold for this marker was proposed to be $>95.5 \%$ (Bondoso et al. 2013). With the exception of the value within group III $(95.3 \%$ ) — which is very close to the proposed threshold-all defined groups meet this criterion in terms of forming the same or different species (Fig. 2 and Table S2). For 16S rRNA gene sequence identities, the general relation patterns of the groups can also be confirmed (Fig. 2 and Table S2). However, the well-established species threshold of $98.7 \%$ (Yarza et al. 2014) does not seem to be applicable for the novel strains as the identity values found appear to be higher than what would be expected from the ANI and $r p o B$ gene sequence identities. However, this is a phenomenon known for the family Planctomycetaceae: e.g. novel species in the genus Planctopirus were found to reach 16S rRNA sequence identity values of $99.7 \%$ and $99.9 \%$ despite ANI values $<95 \%$ (Kohn et al. 2020). Therefore, we propose to interpret $16 \mathrm{~S}$ rRNA gene sequence identity with caution and instead rely more strongly on ANI and $r р о B$ gene sequence identity values for the classification within this taxonomic group. 


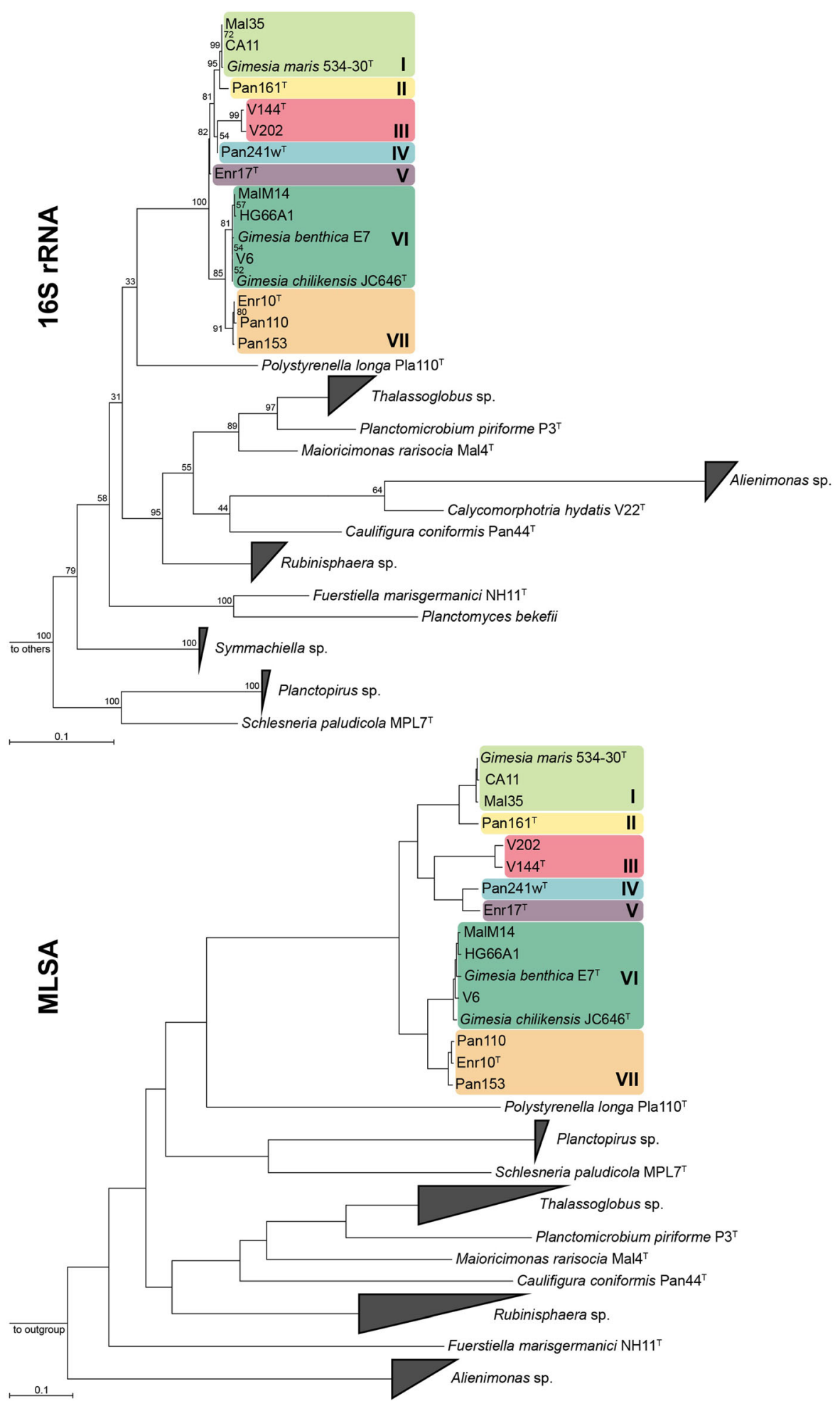


४Fig. 1 Phylogeny of the family Planctomycetaceae based on 16S rRNA gene sequences and whole genome-based multilocus sequence analysis (MLSA). The recently described species of the genera Thalassoglobus, Maioricimonas, Polystyrenella, Alienimonas and Caulifigura are included. The novel strains, the type species of the genus Gimesia, G. maris $534-30^{\mathrm{T}}$, as well as $G$. chilikensis $\mathrm{JC} 6446^{\mathrm{T}}$ and $G$. benthica $\mathrm{E} 7$ are colour-coded depending on their group affiliation: (I) light green, (II) yellow, (III) red, (IV) blue, (V) purple, (VI) dark green and (VII) orange. For the 16S rRNA analysis, maximum likelihood estimationgained bootstrap values after 1000 re-samplings are given at the nodes (in \%). The outgroup consists of three 16S rRNA genes from the PVC superphylum. Members of other planctomycetal families are not shown. For the MLSA-based phylogeny, reliability estimators based on Shimodaira-Hasegawa testing were determined but are not shown as they were always 1 . The outgroup contains three genomes from the family Pirellulaceae. (Color figure online)

Notably, our analysis shows that the two described species G. chilikensis (Kumar et al. 2020) and G. benthica (Wang et al. 2020) do not seem to belong to different species by the here applied measures. We must assume that this inconsistency derives from the fact that $G$. benthica was described only a few weeks after G. chilikensis-and therefore each of these studies only compared the new strain to G. maris, rather than to each other. However, the rules of priority mean that $G$. chilikensis $\mathrm{JC} 646^{\mathrm{T}}$ serves as type strain of the species represented by group VI as it was described first.

\section{Morphology and physiology}

Cell morphology and cell size of strains CA11, Mal35, Pan161 ${ }^{\mathrm{T}}$, Pan241w ${ }^{\mathrm{T}}$, Enr17 ${ }^{\mathrm{T}}, \mathrm{V} 202, \mathrm{~V}_{144^{\mathrm{T}}}$, MalM14, HG66A1, V6, Pan110, Enr10 ${ }^{\mathrm{T}}$ and Pan153 were determined by observation using light microscopy and scanning electron microscopy (SEM) during exponential growth (Figs. 3, 4, 5). All strains form ovoid cells resembling the shape of short-grain rice. The cell sizes are given in Figs. 3, 4, 5 and Table S3. On average, they range from 1.3 to $1.9 \mu \mathrm{m}$ in length and $0.7-1.4 \mu \mathrm{m}$ in width. All strains divide by budding, with the released buds having the same shape as the mother cells. For all strains with appropriate early exponential phase data, the dimorphic life cycle known from $G$. maris $534-30^{\mathrm{T}}$ (Bauld and Staley 1976) could also be observed (strains V202, HG66A1, Enr17 ${ }^{\mathrm{T}}, \mathrm{CA} 11$ and Pan153). All strains form rosettes and larger loose aggregates connected by a stalk formed on the non-budding pole, with fibres covering the entire cell surface. All strains possess flagella at some point of their life cycle and carry crateriform structures as typical for Planctomycetes (Wiegand et al. 2018). All strains grow aerobically. The colonies of all strains are white- to cream-coloured; with the only exceptions being strains V202 and V144 ${ }^{\mathrm{T}}$ (group III) which form orange colonies. Fatty acid analysis revealed palmitic acid $\left(\mathrm{C}_{16: 0}\right)$ and a fatty acid with an equivalent chain length of $15.817\left(\mathrm{C}_{16: 1} \omega 7 c\right.$ or $\mathrm{C}_{15}$ iso 2-OH or $\mathrm{C}_{16: 1} \omega 6 c$ ) to be major components of all strains, accounting for circa $80 \%$ of the total fatty acids (Table 1). The strains are able to grow over $\mathrm{pH}$ ranges of 5-10, with the optima being between 6.5 and 8.5 (Table 2, Fig. S1). While most strains are capable of growth over a broad spectrum within this range, strain V202 only grew at $\mathrm{pH} 7-7.5$. Growth for the 13 examined strains could be observed at temperatures between 10 and $37^{\circ} \mathrm{C}$ with optima between 26 and $33{ }^{\circ} \mathrm{C}$ (Table 2, Fig. S2). Strains belonging to group VI seem to have the highest temperature optima under the tested conditions, while strain Pan $161^{\mathrm{T}}$ (group II) had the lowest. The maximal growth rates in $\mathrm{M} 1 \mathrm{H}$ NAG ASW medium at the optimal temperature were found to be between 0.022 and $0.057 \mathrm{~h}^{-1}$ which corresponds to doubling times between 12 and $32 \mathrm{~h}$ (Table 2). Strains of group III were distinctly the slowest-growing strains under the tested conditions.

Genome analysis indicated that all the novel strains carry genes to allow the conversion of glucose to pyruvate via the Embden-Meyerhof-Parnas and the Entner-Doudoroff pathway. They all seem to be capable of performing gluconeogenesis. The pentose phosphate pathway and the citric acid cycle are fully functional according to presence of respective genes coding for the enzymes involved; however, the glyoxylate shunt is probably absent (Table S4). This is in accordance with the described strains G. maris and $G$. chilikensis. However, there are some features that allow the different groups to be distinguished. While all members of groups III to VII have a heterodimeric transketolase encoded by two adjacent genes, strains from group I and II have one longer gene coding for the transketolase carrying all necessary domains in a single polypeptide chain (Table S4).

Moreover, members of groups I and II carry glucose-6-phosphate isomerase ( $p g i$ ) genes that are less similar to pgi genes of other Planctomycetaceae, but seem more related to pgi of some Acidobacteria, Proteobacteria and Cand. Rokubacteria. 
Differentiation between group I and II can be made as strain Pan $161^{\mathrm{T}}$, the only member of group II, is the only analysed strain that has multiple paralogs of several genes of primary metabolism (e.g. glucose-6phosphate isomerase, phosphoenolpyruvate synthase, transketolase and transaldolase) (Table S4).
Genomic features

The genomes of all strains (Table 3), including the type strain G. maris $834-30^{\mathrm{T}}$ are completely closed and were recently published (Wiegand et al. 2020). The genome sizes of the strains are between 7.22 and $8.29 \mathrm{Mb}$, with members of group III having the
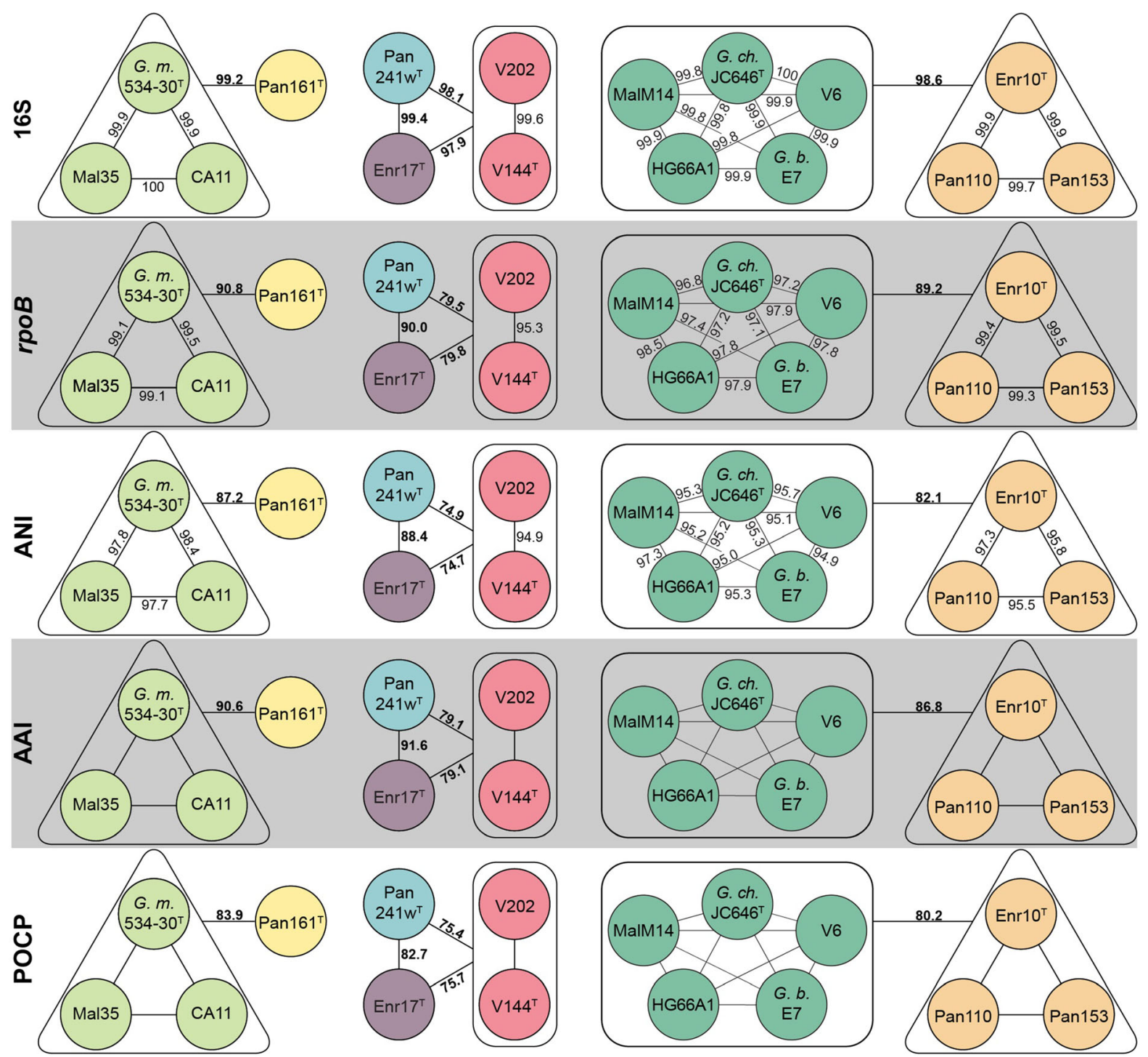

Fig. 2 Phylogenetic markers used for species and genus attribution. Strains suspected to belong to the same species (groups I to VII) have the same colour: (I) light green, (II) yellow, (III) red, (IV) blue, (V) purple, (VI) dark green and (VII) orange. Values (always in \%) determined for average nucleotide identity (ANI), rpoB gene identity and 16S rRNA gene sequence identity can be used to delineate species. They are given in black within groups and in black and bold between

groups, where groups might be suspected to belong together. (Minimal) identity values between clearly resolved groups are not given in the figure but can be found in Table S2. Amino acid identity (AAI) and percentage of conserved proteins (POCP) values are only shown between groups, as these values are used to determine genus affiliation. All values are given in percent. $G$. m.: Gimesia maris, G. ch.: Gimesia chilikensis, G. b.: Gimesia benthica. (Color figure online) 

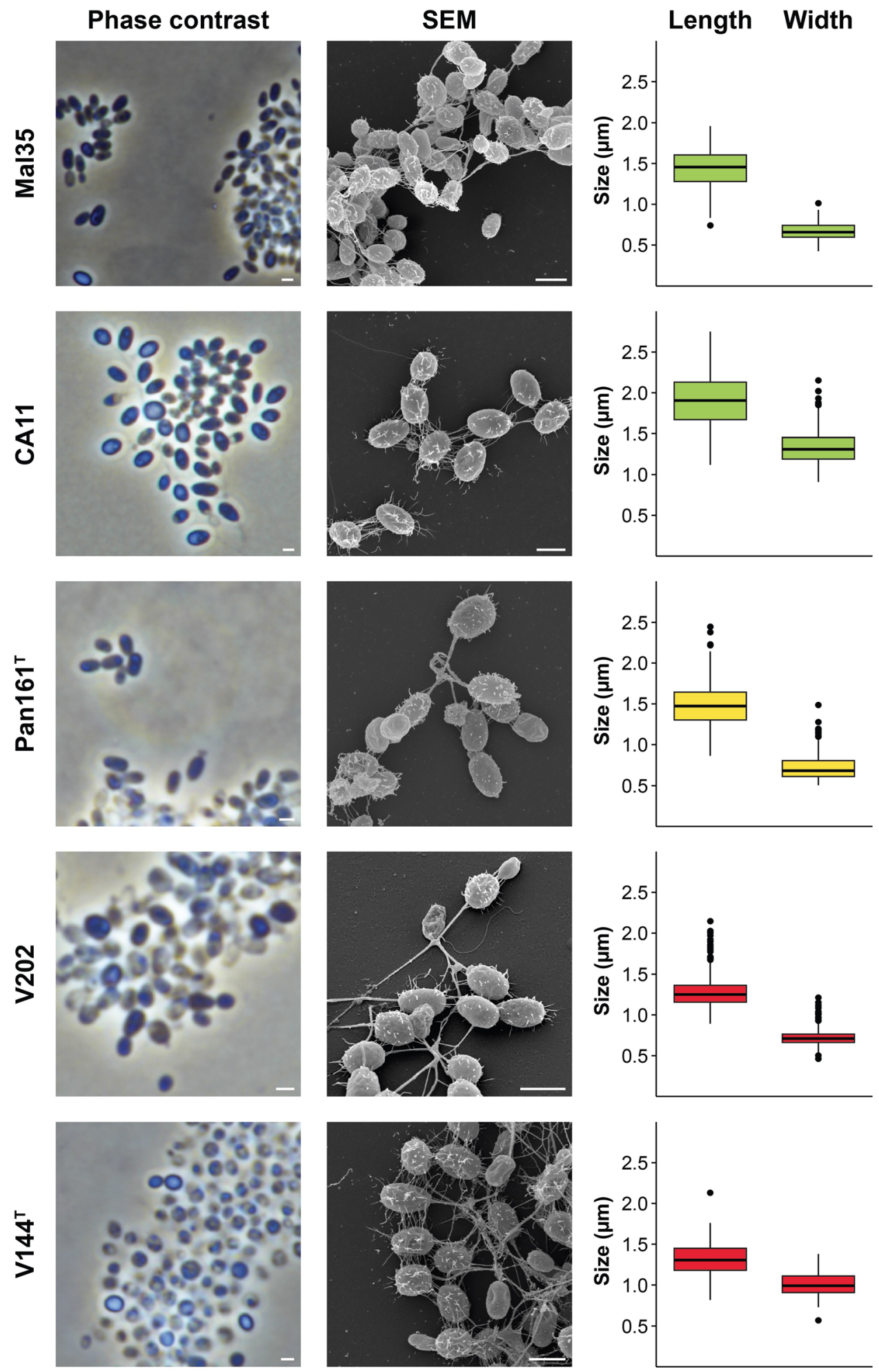

Fig. 3 Microscopy images and cell size plot of strains of groups I (green), II (yellow) and III (red). The figure shows phase contrast as well as scanning electron microscopy (SEM) micrographs. The scale bar is $1 \mu \mathrm{m}$. For determination of the cell sizes at least 100 representative cells were counted manually or by using a semi-automated object count tool. Whiskers of box plots represent $1.5 \times$ interquartile range. (Color figure online) 

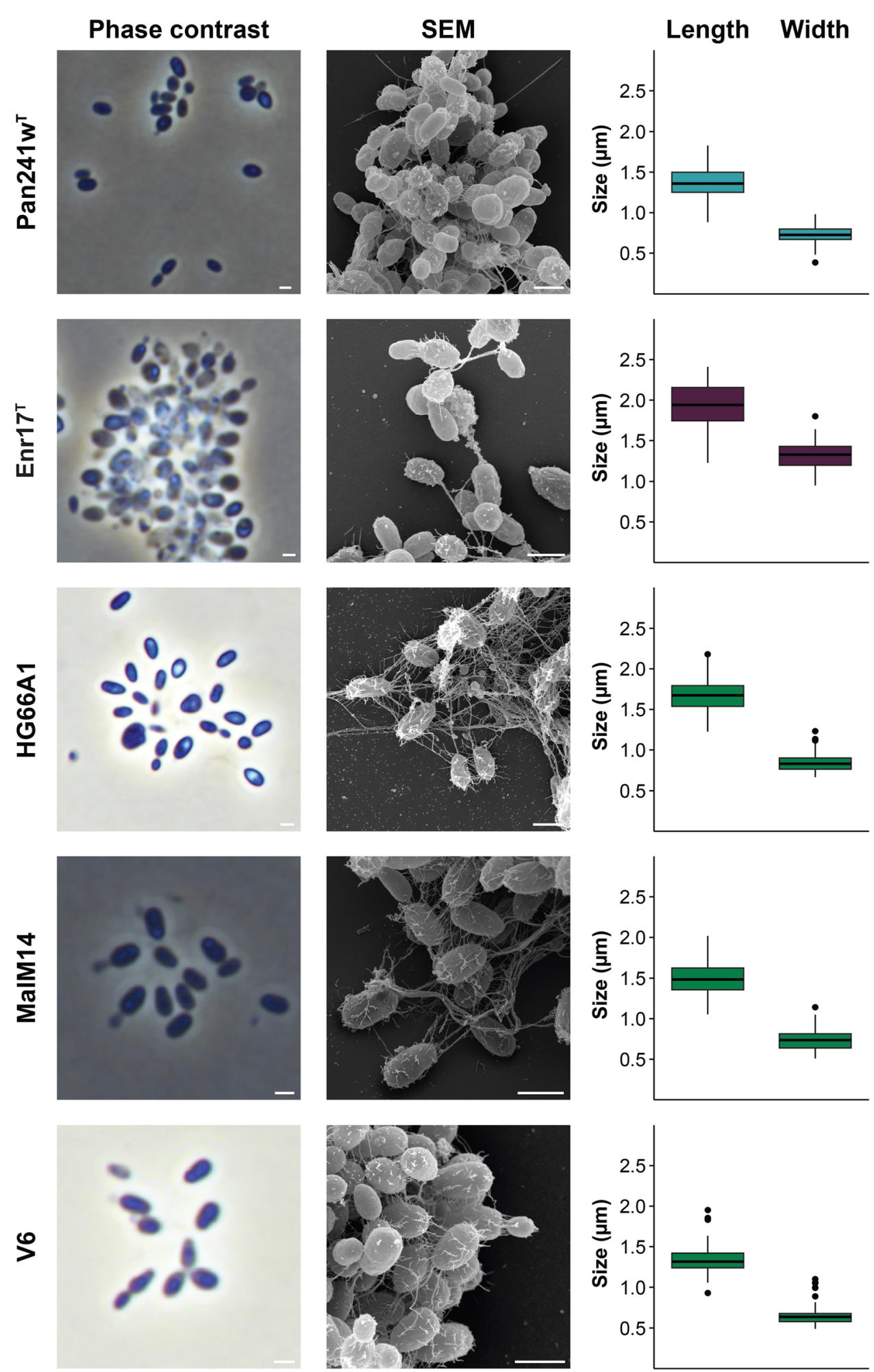

Fig. 4 Microscopy images and cell size plot of strains of groups IV (blue), V (purple) and VI (green). The figure shows phase contrast as well as scanning electron microscopy (SEM) micrographs. The scale bar is $1 \mu \mathrm{m}$. For determination of the cell sizes at least 100 representative cells were counted manually or by using a semi-automated object count tool. Whiskers of box plots represent $1.5 \times$ interquartile range. (Color figure online) 


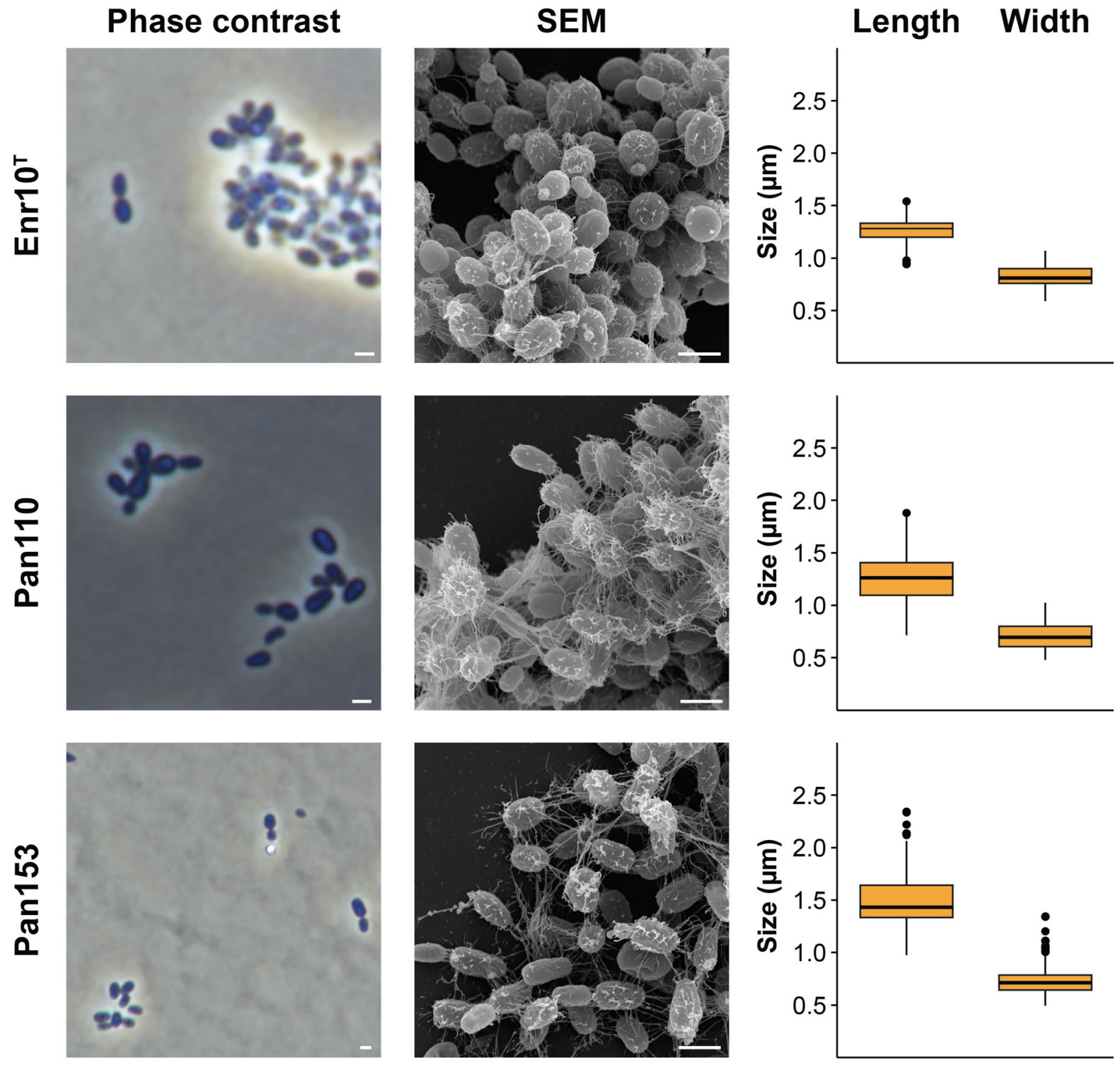

Fig. 5 Microscopy images and cell size plot of strains of group VII. The figure shows phase contrast as well as scanning electron microscopy (SEM) micrographs. The scale bar is $1 \mu \mathrm{m}$. For determination of the cell sizes at least 100 representative

smallest genomes. The $\mathrm{G}+\mathrm{C}$ content of the DNA varies between 45.1 and $53.7 \%$, but is highly conserved within the respective groups. While members of group III each have a low $\mathrm{G}+\mathrm{C}$ content of $45.1 \%$, members of group VII have the highest $\mathrm{G}+\mathrm{C}$ content of 53.3-53.7\%. The number of proteins per $\mathrm{Mb}$ and the number of hypothetical proteins is relatively stable for all strains. Most strains have 63-67 tRNAs, with the exception of strains of group II, which carry 74 and 76 cells were counted manually or by using a semi-automated object count tool. Whiskers of box plots represent $1.5 \times$ interquartile range. (Color figure online)

tRNA genes. Interestingly, while all novel strains have one copy of the 23S rRNA gene and the 5S rRNA gene, ten strains have a duplicated $16 \mathrm{~S}$ rRNA gene.

When locally aligning these new genomes, the phylogeny-based group affiliations become clearly visible (Fig. 6). Genomes within a group share high identity values for long sections, sometimes interrupted by inversions of complete sections. Genomes of 


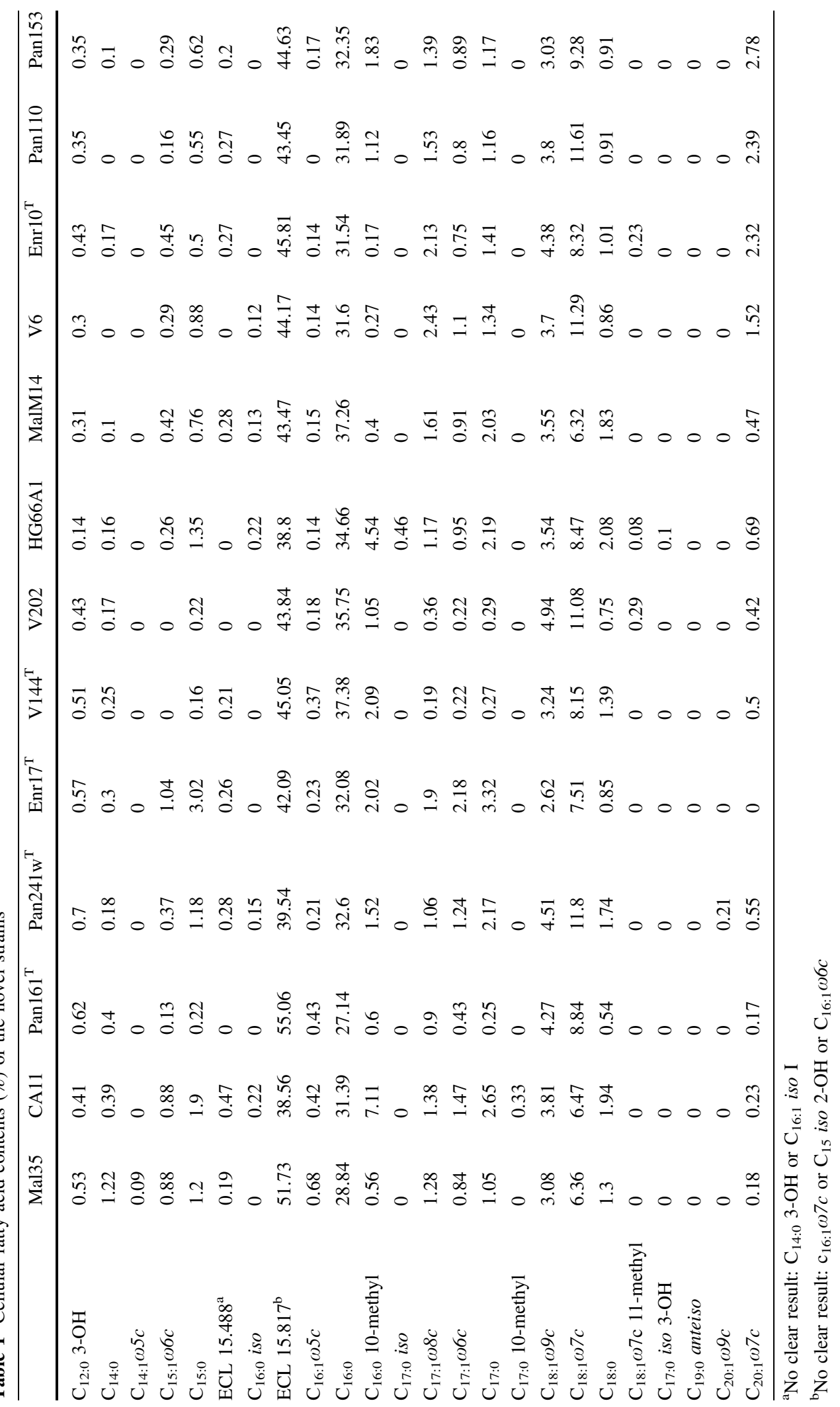


Table $2 \mathrm{pH}$ and temperature optima for growth and maximal growth rates for the novel strains

\begin{tabular}{|c|c|c|c|c|c|c|}
\hline & $\mathrm{pH}$ & $\mathrm{pH}_{\mathrm{opt}}$ & $\mathrm{T}\left({ }^{\circ} \mathrm{C}\right)$ & $\mathrm{T}_{\text {opt }}\left({ }^{\circ} \mathrm{C}\right)$ & Growth rate at $T_{\text {opt }}\left(h^{-1}\right)$ & Generation time at $\mathrm{T}_{\mathrm{opt}}(\mathrm{h})$ \\
\hline Mal35 & $6.0-9.0$ & 7.0 & $10-33$ & 27 & 0.032 & 22 \\
\hline CA11 & $5.0-10.0$ & 7.5 & $10-33$ & 30 & 0.046 & 15 \\
\hline $\operatorname{Pan} 161^{\mathrm{T}}$ & $5.5-10.0$ & 8.5 & $10-30$ & 26 & 0.028 & 25 \\
\hline $\operatorname{Pan} 241 w^{\mathrm{T}}$ & $6.0-10.0$ & 7.5 & $15-33$ & 30 & 0.050 & 14 \\
\hline $\operatorname{Enr} 17^{\mathrm{T}}$ & $6.0-9.5$ & 7.0 & $10-30$ & 27 & 0.046 & 15 \\
\hline $\mathrm{V} 144^{\mathrm{T}}$ & $6.5-9.5$ & 8.0 & $15-30$ & 27 & 0.022 & 32 \\
\hline V202 & $7.0-7.5$ & 7.5 & $15-30$ & 27 & 0.024 & 29 \\
\hline HG66A1 & $5.0-10.0$ & 6.5 & $10-36$ & 33 & 0.057 & 12 \\
\hline MalM14 & $6.0-8.0$ & 7.0 & $15-33$ & 30 & 0.037 & 19 \\
\hline V6 & $5.0-9.5$ & 7.5 & $17-33$ & 33 & 0.037 & 19 \\
\hline Enr $10^{\mathrm{T}}$ & $5.0-10.0$ & 7.5 & $15-37$ & 32 & n.d. & n.d. \\
\hline Pan110 & $5.0-10.0$ & 7.5 & $16-36$ & 31 & 0.039 & 18 \\
\hline Pan 153 & $5.5-9.0$ & 8.5 & $10-36$ & 30 & 0.048 & 14 \\
\hline
\end{tabular}

n.d. not determined

different groups only share fewer sections with lower identity values.

The determined groups are also confirmed by the analysis of their pan genome (Fig. 7). In addition to genes present in all genomes (3-5 o'clock position, Fig. 7), genes present in most genomes (5-6 o'clock, Fig. 7) and genes that are only present in one genome (6-10 o'clock, Fig. 7), there are also genes only found in members of one group (10-12 o'clock, Fig. 7), thereby defining the respective groups.

Taken together, based on the phylogenetic analysis, the alignment of the genomes, the absence and presence of gene clusters as well as morphological and physiological data, we propose that each group (I to VII) corresponds to one species within the genus Gimesia. We propose the names Gimesia algae for strain Pan $161^{\mathrm{T}}$ (group II), Gimesia aquarii for strains V202 and V144 ${ }^{\mathrm{T}}$ (group III), Gimesia alba for strain Pan241w ${ }^{\mathrm{T}}$ (group IV), Gimesia fumaroli for strain Enr17 $7^{\mathrm{T}}$ (group V), and Gimesia panareensis for strains Enr10 ${ }^{\mathrm{T}}$, Pan110 and Pan153 (group VII), whilst we conclude that strains CA11 (= DSM $101991=$ LMG 29074) and Mal35 (= LMG $31348=$ CECT 9838 = VKM B-3428) are novel isolates of $G$. maris (group I) and strains V6, HG66A1 and MalM14 are novel isolates of G. chilikensis (group VI).
Emended description of the genus Gimesia (Scheuner et al. 2014) Kumar et al. 2020

The description is the one given previously (Kumar et al. 2020), with the following modifications. Major fatty acids are palmitic acid (16:0) and a fatty acid with the equivalent chain length of 15.817 . The $\mathrm{G}+\mathrm{C}$ content of the genomic DNA is between 45.1 and $53.7 \%$.

\section{Emended description of Gimesia chilikensis Kumar et al. 2020}

The description is the one given previously (Kumar et al. 2020), with the following modifications. Cell sizes are 1.2-1.9 × 0.7-1.0 $\mu \mathrm{m}$. Most cells are at least temporarily flagellated and motile. Most cells possess stalks (usually about the length of the cell) opposite of the budding pole. Most cells have crateriform structures covering the entire cell surface. Different strains of the species have temperature optima for growth between 25 and $33{ }^{\circ} \mathrm{C}$.

Additional strains belonging to the species include HG66A1 (= DSM 100825 = LMG 29015; genome acc. no. CP036266, 16S rRNA acc. no. MK554525), V6 (= DSM 29811 = LMG 29078; genome acc. no. CP036347, 16S rRNA acc. no. MK554511) and MalM14 (= CECT 30191 = STH00944, Jena Microbial Resource Collection (JMRC), = LMG 29132; 


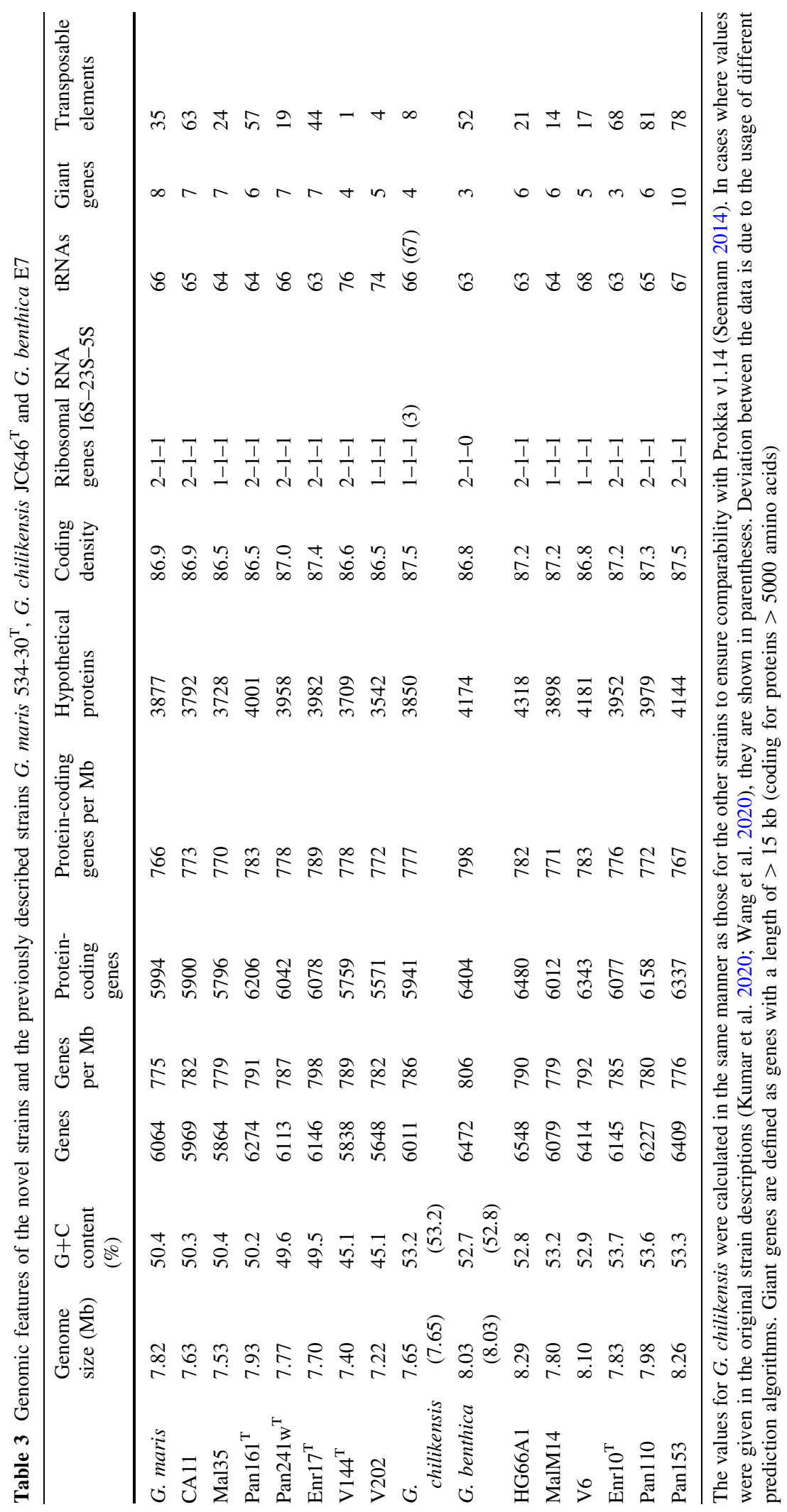


G. maris $534-30^{\top}$

CA11

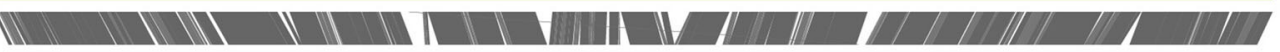

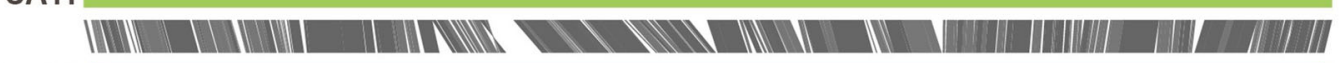
Mal35

Pan161 ${ }^{\top}$
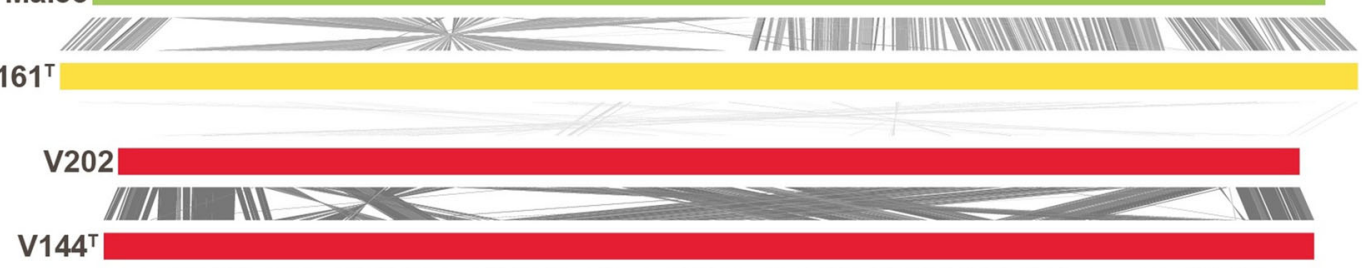

Pan241 $w^{\top}$

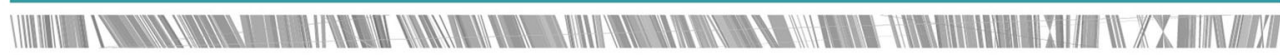

Enr17

IIIII)

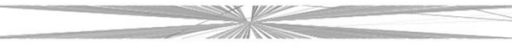

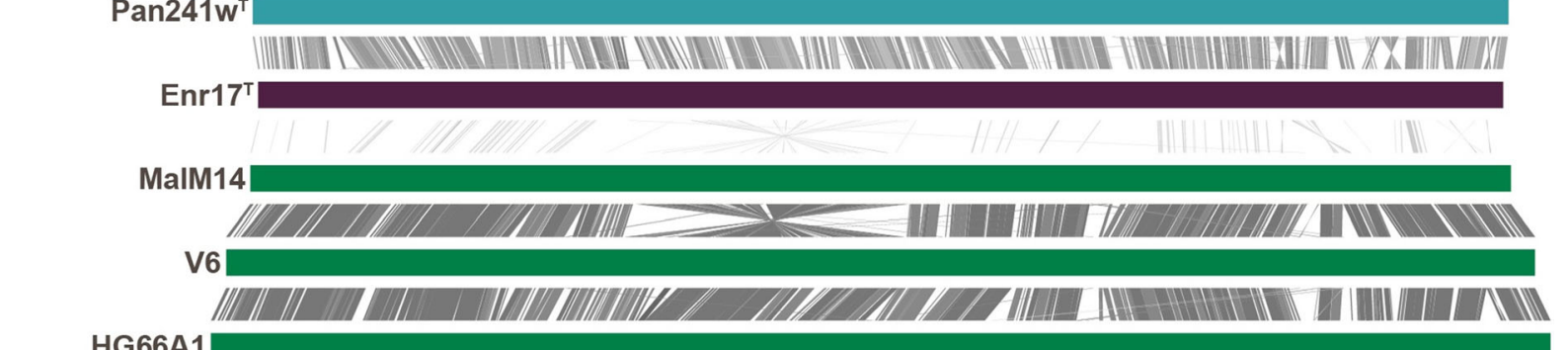

HG66A1

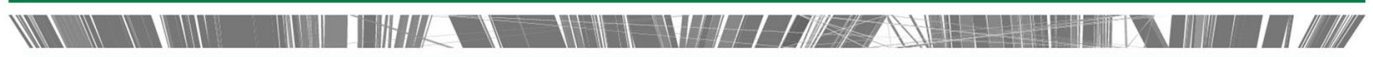

G. benthica $\mathrm{E7}$

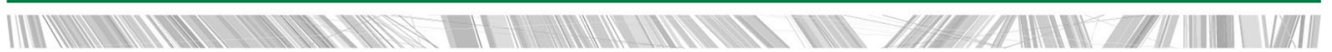

Pan110

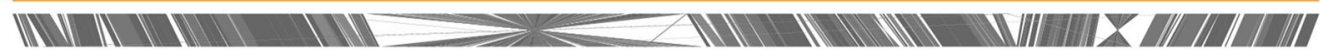

Enr10 $10^{\top}$

Pan153

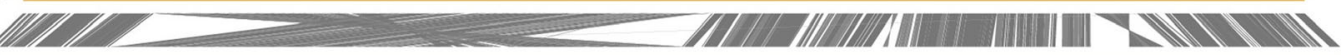

$2 \mathrm{Mb}$

Fig. 6 Nucleotide-based local alignment of complete genomes. Each genome is represented by a coloured bar corresponding to its size and group affiliation ((I) light green, (II) yellow, (III) red, (IV) blue, (V) purple, (VI) dark green and (VII) orange). Identity

genome acc. no. CP036342, 16S rRNA acc. no. MK554514), isolated from rocky tide land (Helgoland Island, Germany), a seawater aquarium (Braunschweig, Germany) and marine sediment (Mallorca Island, Spain), respectively.

Description of Gimesia alba sp. nov.

Gimesia alba (al'ba. L. fem. adj. alba white, corresponding to the whitish colour of the cells).

Cells are short grain-rice-shaped (size: $1.4 \pm 0.2 \times 0.7 \pm 0.1 \mu \mathrm{m})$ and form rosettes which assemble into aggregates. Cells contain crateriform structures covering the entire cell surface and have a values between $73 \%$ (light grey) and $100 \%$ (dark grey) are given for homologous sections. G. chilikensis was not included in the analysis as its genome is not closed. (Color figure online)

stalk (usually about the length of the cell) opposite of the budding pole. The temperature range for growth is $15-33{ }^{\circ} \mathrm{C}$ (optimum $30{ }^{\circ} \mathrm{C}$ ) and for $\mathrm{pH}$ is $6-10$ (optimum 7.5). Colonies are white. The genome size of the type strain is $7.77 \mathrm{Mb}$ with a $\mathrm{G}+\mathrm{C}$ content of $49.6 \%$.

The type strain is $\operatorname{Pan} 241 \mathrm{w}^{\mathrm{T}}$ (= DSM $100744^{\mathrm{T}-}$ $=$ LMG $31345^{\mathrm{T}}=$ CECT $9841^{\mathrm{T}}=$ VKM B-3430 ${ }^{\mathrm{T}}$ ), isolated from organic material from the hydrothermal vent system close to Panarea Island, Italy. The type strain genome (acc. no. CP036269) and 16S rRNA gene sequence (acc. no. MK554516) are available from GenBank. 


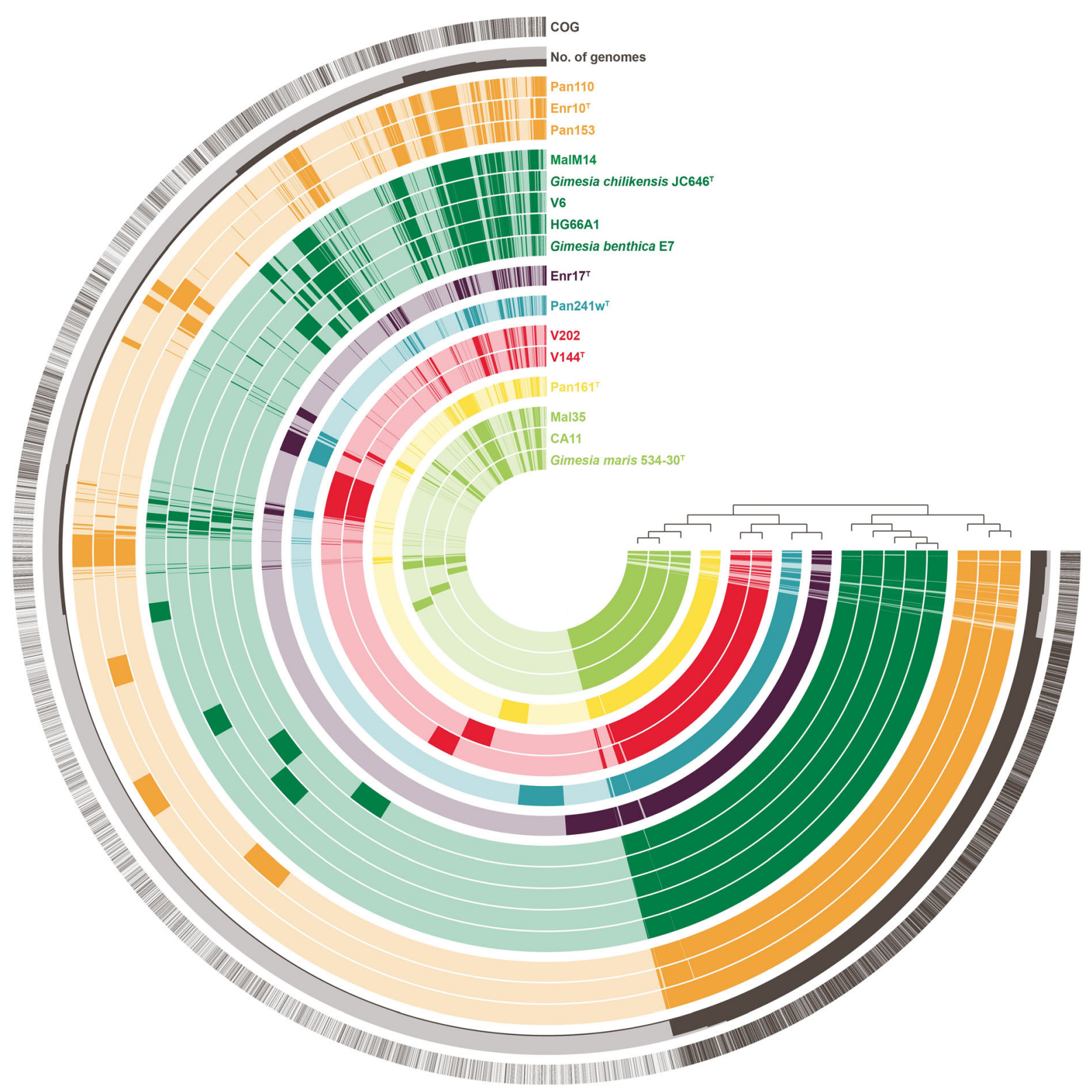

Fig. 7 Pan genome of all strains described here. Each open circle represents the pan genome of all strains but is coloured darker when the gene is present in the respective genome. Colours represent the group affiliation of the genomes: (I) light green, (II) yellow, (III) red, (IV) blue, (V) purple, (VI) dark

\section{Description of Gimesia algae sp. nov.}

Gimesia algae (al'gae. L. gen. n. algae of an alga, corresponding to the isolation of the type strain from an alga).

Cells are short grain-rice-shaped (size: $1.5 \pm 0.3 \times 0.7 \pm 0.2 \mu \mathrm{m})$ and form rosettes which green and (VII) orange. The trees reflect on the relatedness of the strains based on the absence/presence of genes. The outer circles show the number of genomes in which a gene is present and if it has a COG annotation (dark grey). (Color figure online)

assemble into branched aggregates. Cells contain crateriform structures covering the entire cell surface and have a stalk (usually about the length of the cell) opposite of the budding pole. Grows at $10-30{ }^{\circ} \mathrm{C}$ (optimum $26^{\circ} \mathrm{C}$ ) and at $\mathrm{pH}$ 5.5-10.0 (optimum 7.5). Colonies are white. The genome size of the type strain is $7.93 \mathrm{Mb}$ with a $\mathrm{G}+\mathrm{C}$ content of $50.2 \%$. 
The type strain is $\operatorname{Pan}_{161}{ }^{\mathrm{T}}$ (CECT $30192^{\mathrm{T}}=$ STH00943 ${ }^{\mathrm{T}}$, Jena Microbial Resource Collection $(J M R C),=$ LMG $29130^{\mathrm{T}}$ ), isolated from an alga collected from the hydrothermal vent system close to Panarea Island, Italy. The type strain genome (acc. no. CP036343) and 16S rRNA gene sequence (acc. no. MK554515) are available from GenBank.

Description of Gimesia aquarii sp. nov.

Gimesia aquarii (a.qua'ri.i. L. gen. n. aquarii of an aquarium, corresponding to the origin of the type strain from an aquarium).

Cells are short grain-rice-shaped (type strain cell size: $1.3 \pm 0.2 \times 1.0 \pm 0.1 \mu \mathrm{m}$ ) and form rosettes which assemble into branched aggregates. Cells have crateriform structures covering the entire cell surface and a stalk (usually about the length of the cell) opposite of the budding pole. The temperature range for growth is $15-30{ }^{\circ} \mathrm{C}$ (optimum $27{ }^{\circ} \mathrm{C}$ ) and $\mathrm{pH}$ range is 6.5-9.5 (optimum 8.0). Colonies are orange. The genome size of the type strain is $7.40 \mathrm{Mb}$ with a $\mathrm{G}+\mathrm{C}$ content of $45.1 \%$.

The type strain is $\mathrm{V} 144^{\mathrm{T}}\left(=\mathrm{DSM} 101710^{\mathrm{T}}=\mathrm{VKM}\right.$ $\left.\mathrm{B}-3433^{\mathrm{T}}\right)$, isolated from an ornamental seawater aquarium. The type strain genome (acc. no. CP037920) and 16S rRNA gene sequence (acc. no. MK554556) are available from GenBank. A second strain belonging to the species is V202 (= DSM 104302 = VKM B-3440; genome acc. no. CP037422, 16S rRNA acc. no. MK554536), isolated from the same seawater aquarium as the type strain.

\section{Description of Gimesia fumaroli sp. nov.}

Gimesia fumaroli (fu.ma.ro'li. L. gen. n. fumaroli of a fumarole, corresponding to the provenance of the type strain from a fumarole).

Cells are short grain-rice-shaped (size: $1.9 \pm 0.3 \times 1.3 \pm 0.2 \mu \mathrm{m}$ ) and form rosettes which assemble into loose aggregates. Cells have crateriform structures covering the entire cell surface and a stalk (usually about the length of the cell) opposite of the budding pole. Grows at $10-30{ }^{\circ} \mathrm{C}$ (optimum $27^{\circ} \mathrm{C}$ ) and at $\mathrm{pH}$ 6.0-9.5 (optimum 6.5). Colonies are white. The genome size of the type strain is $7.70 \mathrm{Mb}$ with a $\mathrm{G}+\mathrm{C}$ content of $49.5 \%$.

The type strain is $\mathrm{Enr} 17^{\mathrm{T}}$ (= DSM $100710^{\mathrm{T}-}$ $=$ VKM B $-3429^{\mathrm{T}}$, synonym Enrichment17), isolated from a marine hot lake gas escape at Panarea island, Italy. The type strain genome (acc. no. CP037452) and $16 \mathrm{~S}$ rRNA gene sequence (acc. no. MK554524) are available from GenBank.

\section{Description of Gimesia panareensis sp. nov.}

Gimesia panareensis (pa.na.re.en'sis. N.L. fem. adj. panareensis pertaining to Panarea, corresponding to the origin of the type strain from Panarea Island, Italy).

Cells are short grain-rice-shaped (type strain cell size: $1.3 \pm 0.1 \times 0.8 \pm 0.1 \mu \mathrm{m})$ and form rosettes which assemble into aggregates. Cells have crateriform structures covering the entire cell surface and a stalk (usually about the length of the cell) opposite of the budding pole. Grows at $15-37{ }^{\circ} \mathrm{C}$ (optimum $32{ }^{\circ} \mathrm{C}$ ) and at pH 5-10 (optimum 7.5). Colonies are cream-coloured. The genome size of the type strain is $7.83 \mathrm{Mb}$ with a $\mathrm{G}+\mathrm{C}$ content of $53.3 \%$.

The type strain is Enr10 $0^{\mathrm{T}}$ (= DSM $100416^{\mathrm{T}-}$ $=$ LMG $29082^{\mathrm{T}}$, synonym Enrichment10), isolated from a rust biofilm at a hot lake gas escape close to Panarea Island, Italy. The type strain genome (acc. no. CP037421) and 16S rRNA gene sequence (acc. no. MK554508) are available from GenBank.

Additional strains belonging to the species are Pan110 (= DSM 100280 = CECT 9839; genome acc. no. CP036277, 16S rRNA acc. no. MK559981) and Pan153 (= DSM 100430 = LMG 29134; genome acc. no. CP036317, 16S rRNA acc. no. MK554531), both isolated from sediments near a newly formed hot lake gas escape at Panarea Island, Italy.

Acknowledgements Open Access funding enabled and organized by Projekt DEAL. Part of this research was funded by the Deutsche Forschungsgemeinschaft Grants KA 4967/1-1 and JO 893/4-1, Grant ALWOP.308 of the Nederlandse Organisatie voor Wetenschappelijk Onderzoek (NWO), SIAM (Soehngen Institute for Anaerobic Microbiology) Grant no. 024002002 and the Radboud Excellence fellowship. We thank Ina Schleicher for skillful technical assistance and the staff from the Identification Service of the German Collection of Microorganisms and Cell Cultures (DSMZ) for the analysis of fatty acids. We also thank Brian Tindall and Regine Fähnrich from the DSMZ as well as the staff from the strain collections in Russia, Belgium and Spain for support during strain deposition. We thank Alfred M. Spormann (Stanford, USA) as well as the Aquarius Dive Shop Monterey and the Hopkins Marine Station for sampling support in California. We thank the Scientific Diving Center of the Bergakademie Freiberg, Germany, Thomas Pohl, Peter Hornburger and all participants of the 2013 Panarea Expedition for sampling support. We thank Jörn 
Petersen (DSMZ) and the Biological Institute Heligoland (BAH) for sampling support on Helgoland.

Author contributions SW wrote the manuscript draft and performed the genome-based and phylogenetic analyses, MJ, $\mathrm{AH}$ and PR isolated the strains and performed the initial cultivation, strain deposition, and physiological analyses, SHP and $\mathrm{CB}$ performed the light microscopic analysis, MSMJ, A-KK and NK contributed to text preparation and revised the manuscript, MR performed the electron microscopic analysis, CJ took the samples, supervised PR and AH and the study. All authors read and approved the final version of the manuscript.

\section{Compliance with ethical standards}

Conflict of interest The authors declare that they have no conflict of interest.

Ethical statement This article does not contain any studies with animals performed by any of the authors.

Open Access This article is licensed under a Creative Commons Attribution 4.0 International License, which permits use, sharing, adaptation, distribution and reproduction in any medium or format, as long as you give appropriate credit to the original author(s) and the source, provide a link to the Creative Commons licence, and indicate if changes were made. The images or other third party material in this article are included in the article's Creative Commons licence, unless indicated otherwise in a credit line to the material. If material is not included in the article's Creative Commons licence and your intended use is not permitted by statutory regulation or exceeds the permitted use, you will need to obtain permission directly from the copyright holder. To view a copy of this licence, visit http://creativecommons.org/licenses/by/4.0/.

\section{References}

Acehan D, Santarella-Mellwig R, Devos DP (2013) A bacterial tubulovesicular network. J Cell Sci 127:277-280

Bauld J, Staley JT (1976) Planctomyces maris sp. nov.: a marine isolate of the Planctomyces-Blastocaulis group of budding bacteria. J Gen Microbiol 97:45-55

Bengtsson MM, Øvreås L (2010) Planctomycetes dominate biofilms on surfaces of the kelp Laminaria hyperborea. BMC Microbiol 10:261

Bengtsson MM, Sjøtun K, Lanzén A, Øvreås L (2012) Bacterial diversity in relation to secondary production and succession on surfaces of the kelp Laminaria hyperborea. ISME J 6:2188-2198

Boedeker C, Schuler M, Reintjes G, Jeske O, van Teeseling MC, Jogler M, Rast P, Borchert D, Devos DP, Kucklick M, Schaffer M, Kolter R, van Niftrik L, Engelmann S, Amann R, Rohde M, Engelhardt H, Jogler C (2017) Determining the bacterial cell biology of Planctomycetes. Nat Commun $8: 14853$
Boersma AS, Kallscheuer N, Wiegand S, Rast P, Peeters SH, Mesman RJ, Heuer A, Boedeker C, Jetten MS, Rohde M, Joger M, Jogler C (2019) Alienimonas californiensis gen. nov. sp. nov., a novel Planctomycete isolated from the kelp forest in Monterey Bay. Antonie Van Leeuwenhoek. https://doi.org/10.1007/s10482-019-01367-4

Bondoso J, Harder J, Lage OM (2013) rpoB gene as a novel molecular marker to infer phylogeny in Planctomycetales. Antonie Van Leeuwenhoek 104:477-488

Bondoso J, Balague V, Gasol JM, Lage OM (2014) Community composition of the Planctomycetes associated with different macroalgae. FEMS Microbiol Ecol 88:445-456

Bondoso J, Albuquerque L, Nobre MF, Lobo-da-Cunha A, da Costa MS, Lage OM (2015) Roseimaritima ulvae gen. nov., sp. nov. and Rubripirellula obstinata gen. nov., sp. nov. two novel planctomycetes isolated from the epiphytic community of macroalgae. Syst Appl Microbiol 38:8-15

Bondoso J, Godoy-Vitorino F, Balague V, Gasol JM, Harder J, Lage OM (2017) Epiphytic Planctomycetes communities associated with three main groups of macroalgae. FEMS Microbiol Ecol 93:fiw255

Castresana J (2000) Selection of conserved blocks from multiple alignments for their use in phylogenetic analysis. Mol Biol Evol 17:540-552

Dedysh SN, Henke P, Ivanova AA, Kulichevskaya IS, Philippov DA, Meier-Kolthoff JP, Goker M, Huang S, Overmann J (2020a) 100-year-old enigma solved: identification, genomic characterization and biogeography of the yet uncultured Planctomyces bekefii. Environ Microbiol 22:198-211

Dedysh SN, Kulichevskaya IS, Beletsky AV, Ivanova AA, Rijpstra WIC, Damste JSS, Mardanov AV, Ravin NV (2020b) Lacipirellula parvula gen. nov., sp. nov., representing a lineage of planctomycetes widespread in lowoxygen habitats, description of the family Lacipirellulaceae fam. nov. and proposal of the orders Pirellulales ord. nov., Gemmatales ord. nov. and Isosphaerales ord. nov. Syst Appl Microbiol 43:126050

Delmont TO, Eren AM (2018) Linking pangenomes and metagenomes: the Prochlorococcus metapangenome. PeerJ 6:e4320

Edgar RC (2004) MUSCLE: multiple sequence alignment with high accuracy and high throughput. Nucleic Acids Res 32:1792-1797

Eren AM, Esen OC, Quince C, Vineis JH, Morrison HG, Sogin ML, Delmont TO (2015) Anvi'o: an advanced analysis and visualization platform for 'omics data. PeerJ 3:e1319

Gimesi N (1924) Hydrobiologiai talmanyok (Hydrobiologische Studien). I. Planktomyces Bekefii Gim. nov. gen. et sp. Budapest, Kiadja a Magyar Ciszterci. pp. 1-8

Graça AP, Calisto R, Lage OM (2016) Planctomycetes as novel source of bioactive molecules. Front Microbiol 7:1241

Jeske O, Jogler M, Petersen J, Sikorski J, Jogler C (2013) From genome mining to phenotypic microarrays: Planctomycetes as source for novel bioactive molecules. Antonie Van Leeuwenhoek 104:551-567

Jeske O, Schüler M, Schumann P, Schneider A, Boedeker C, Jogler M, Bollschweiler D, Rohde M, Mayer C, Engelhardt H, Spring S, Jogler C (2015) Planctomycetes do possess a peptidoglycan cell wall. Nat Commun 6:7116 
Jeske O, Surup F, Ketteniß M, Rast P, Förster B, Jogler M, Wink J, Jogler C (2016) Developing techniques for the utilization of Planctomycetes as producers of bioactive molecules. Front Microbiol 7:1242

Jogler C, Waldmann J, Huang X, Jogler M, Glöckner FO, Mascher T, Kolter R (2012) Identification of proteins likely to be involved in morphogenesis, cell division, and signal transduction in Planctomycetes by comparative genomics. J Bacteriol 194:6419-6430

Kallscheuer N, Moreira C, Airs R, Llewellyn CA, Wiegand S, Jogler C, Lage OM (2019) Pink-and orange-pigmented Planctomycetes produce saproxanthin-type carotenoids including a rare C45 carotenoid. Environ Microbiol Rep 11:741-748

Kallscheuer N, Jeske O, Sandargo B, Boedeker C, Wiegand S, Bartling P, Jogler M, Rohde M, Petersen J, Medema MH, Surup F, Jogler C (2020a) The planctomycete Stieleria maiorica Mal15 ${ }^{\mathrm{T}}$ employs stieleriacines to alter the species composition in marine biofilms. Commun Biol 3:303

Kallscheuer N, Wiegand S, Boedeker C, Peeters SH, Jogler M, Heuer A, Jetten MS, Rohde M, Jogler C (2020b) Caulifigura coniformis gen. nov., sp. nov., a novel member of the family Planctomycetaceae isolated from a red biofilm sampled in a hydrothermal area. Antonie Van Leeuwenhoek. https://doi.org/10.1007/s10482-020-01439-w

Kämpfer P, Kroppenstedt RM (1996) Numerical analysis of fatty acid patterns of coryneform bacteria and related taxa. Can J Microbiol 42:989-1005

Kim M, Oh HS, Park SC, Chun J (2014) Towards a taxonomic coherence between average nucleotide identity and $16 \mathrm{~S}$ rRNA gene sequence similarity for species demarcation of prokaryotes. Int J Syst Evol Microbiol 64:346-351

Kohn T, Heuer A, Jogler M, Vollmers J, Boedeker C, Bunk B, Rast P, Borchert D, Glöckner I, Freese HM, Klenk HP, Overmann J, Kaster AK, Rohde M, Wiegand S, Jogler C (2016) Fuerstia marisgermanicae gen. nov., sp. nov., an unusual member of the phylum Planctomycetes from the German Wadden Sea. Front Microbiol 7:2079

Kohn T, Heuer A, Jogler M, Vollmers J, Boedeker C, Bunk B, Rast P, Borchert D, Glöckner I, Freese HM, Klenk HP, Overmann J, Kaster AK, Rohde M, Wiegand S, Jogler C (2019) Corrigendum: Fuerstia marisgermanicae gen. nov., sp. nov., an unusual member of the phylum Planctomycetes from the German Wadden Sea. Front Microbiol 10:1029

Kohn T, Wiegand S, Boedeker C, Rast P, Heuer A, Jetten MSM, Schuler M, Becker S, Rohde C, Muller RW, Brummer F, Rohde M, Engelhardt H, Jogler M, Jogler C (2020) Planctopirus ephydatiae, a novel Planctomycete isolated from a freshwater sponge. Syst Appl Microbiol 43:126022

Kumar D, Gaurav K, PK S, A S, Uppada J, Ch. S, Ch.V. R (2020) Gimesia chilikensis sp. nov., a haloalkali-tolerant planctomycete isolated from Chilika lagoon and emended description of the genus Gimesia. Int J Syst Evol Microbiol 70:3647-3655

Kuykendall LD, Roy MA, O’Neill JJ, Devine TE (1988) Fatty acids, antibiotic resistance, and deoxyribonucleic acid homology groups of Bradyrhizobium japonicum. Int J Syst Evol Microbiol 38:358-361

Lachnit T, Fischer M, Kunzel S, Baines JF, Harder T (2013) Compounds associated with algal surfaces mediate epiphytic colonization of the marine macroalga Fucus vesiculosus. FEMS Microbiol Ecol 84:411-420

Lage OM, Bondoso J (2014) Planctomycetes and macroalgae, a striking association. Front Microbiol 5:267

Lechner M, Findeiss S, Steiner L, Marz M, Stadler PF, Prohaska SJ (2011) Proteinortho: detection of (co-)orthologs in large-scale analysis. BMC Bioinform 12:124

Lee I, Ouk Kim Y, Park SC, Chun J (2016) OrthoANI: an improved algorithm and software for calculating average nucleotide identity. Int $J$ Syst Evol Microbiol 66:1100-1103

Letunic I, Bork P (2019) Interactive Tree Of Life (iTOL) v4: recent updates and new developments. Nucleic Acids Res 1:gkz239

Luo C, Rodriguez RL, Konstantinidis KT (2014) MyTaxa: an advanced taxonomic classifier for genomic and metagenomic sequences. Nucleic Acids Res 42:e73

Miller LT (1982) Single derivatization method for routine analysis of bacterial whole-cell fatty acid methyl esters, including hydroxy acids. J Clin Microbiol 16:584-586

Mitchell AL, Attwood TK, Babbitt PC, Blum M, Bork P, Bridge A, Brown SD, Chang HY, El-Gebali S, Fraser MI, Gough J, Haft DR, Huang H, Letunic I, Lopez R, Luciani A, Madeira F, Marchler-Bauer A, Mi H, Natale DA, Necci M, Nuka G, Orengo C, Pandurangan AP, Paysan-Lafosse T, Pesseat S, Potter SC, Qureshi MA, Rawlings ND, Redaschi N, Richardson LJ, Rivoire C, Salazar GA, Sangrador-Vegas A, Sigrist CJA, Sillitoe I, Sutton GG, Thanki N, Thomas PD, Tosatto SCE, Yong SY, Finn RD (2019) InterPro in 2019: improving coverage, classification and access to protein sequence annotations. Nucleic Acids Res 47:D351-D360

Peeters SH, Wiegand S, Kallscheuer N, Jogler M, Heuer A, Jetten MS, Boedeker C, Rohde M, Jogler C (2020) Description of Polystyrenella longa gen. nov., sp. nov., isolated from polystyrene particles incubated in the Baltic Sea. Antonie Van Leeuwenhoek. https://doi.org/10.1007/ s10482-020-01406-5

Pilhofer M, Rappl K, Eckl C, Bauer AP, Ludwig W, Schleifer KH, Petroni G (2008) Characterization and evolution of cell division and cell wall synthesis genes in the bacterial phyla Verrucomicrobia, Lentisphaerae, Chlamydiae, and Planctomycetes and phylogenetic comparison with rRNA genes. J Bacteriol 190:3192-3202

Price MN, Dehal PS, Arkin AP (2010) FastTree 2-approximately maximum-likelihood trees for large alignments. PLoS ONE 5:e9490

Pruesse E, Peplies J, Glöckner FO (2012) SINA: accurate highthroughput multiple sequence alignment of ribosomal RNA genes. Bioinformatics 28:1823-1829

Qin Q-L, Xie B-B, Zhang X-Y, Chen X-L, Zhou B-C, Zhou J, Oren A, Zhang Y-Z (2014) A proposed genus boundary for the prokaryotes based on genomic insights. J Bacteriol 196:2210-2215

Rast P, Glöckner I, Boedeker C, Jeske O, Wiegand S, Reinhardt R, Schumann P, Rohde M, Spring S, Glöckner FO, Jogler C, Jogler M (2017) Three novel species with peptidoglycan cell walls form the new genus Lacunisphaera gen. nov. in the family Opitutaceae of the verrucomicrobial subdivision 4. Front Microbiol 8:202 
Rivas-Marin E, Wiegand S, Kallscheuer N, Jogler M, Peeters $\mathrm{SH}$, Heuer A, Jetten MS, Boedeker C, Rohde M, Devos DP, Jogler C (2020a) Maioricimonas rarisocia gen. nov., sp. nov., a novel planctomycete isolated from marine sediments close to Mallorca Island. Antonie Van Leeuwenhoek. https://doi.org/10.1007/s10482-020-01436-Z

Rivas-Marin E, Wiegand S, Kallscheuer N, Jogler M, Peeters SH, Heuer A, Jetten MS, Boedeker C, Rohde M, Devos DP, Jogler C (2020b) Thalassoglobus polymorphus sp. nov., a novel Planctomycete isolated close to a public beach of Mallorca Island. Antonie Van Leeuwenhoek. https://doi. org/10.1007/s10482-020-01437-y

Rodriguez-R LM, Konstantinidis KT (2016) The enveomics collection: a toolbox for specialized analyses of microbial genomes and metagenomes. PeerJ 4:e1900v1

Scheuner C, Tindall B, Lu M, Nolan M, Lapidus A, Cheng J-F, Goodwin L, Pitluck S, Huntemann M, Liolios K, Pagani I, Mavromatis K, Ivanova N, Pati A, Chen A, Palaniappan K, Jeffries C, Hauser L, Land M, Mwirichia R, Rohde R, Abt B, Detter J, Woyke T, Eisen J, Markowitz V, Hugenholtz P, Göker M, Kyrpides N, Klenk H-P (2014) Complete genome sequence of Planctomyces brasiliensis type strain $\left(\mathrm{DSM} 5305^{\mathrm{T}}\right.$ ), phylogenomic analysis and reclassification of Planctomycetes including the descriptions of Gimesia gen. nov., Planctopirus gen. nov. and Rubinisphaera gen. nov. and emended descriptions of the order Planctomycetales and the family Planctomycetaceae. Stand Genomic Sci 9:10

Seemann T (2014) Prokka: rapid prokaryotic genome annotation. Bioinformatics 30:2068-2069

Sievers F, Wilm A, Dineen D, Gibson TJ, Karplus K, Li W, Lopez R, McWilliam H, Remmert M, Söding J (2011) Fast, scalable generation of high-quality protein multiple sequence alignments using Clustal Omega. Mol Syst Biol 7:539

Stamatakis A (2014) RAxML version 8: a tool for phylogenetic analysis and post-analysis of large phylogenies. Bioinformatics 30:1312-1313

Sullivan MJ, Petty NK, Beatson SA (2011) Easyfig: a genome comparison visualizer. Bioinformatics 27:1009-1010

UniProt C (2019) UniProt: a worldwide hub of protein knowledge. Nucleic Acids Res 47:D506-D515

van Teeseling MC, Mesman RJ, Kuru E, Espaillat A, Cava F, Brun YV, VanNieuwenhze MS, Kartal B, van Niftrik L (2015) Anammox Planctomycetes have a peptidoglycan cell wall. Nat Commun 6:6878
Vitorino I, Albuquerque L, Wiegand S, Kallscheuer N, da Costa MS, Lobo-da-Cunha A, Jogler C, Lage OM (2020) Alienimonas chondri sp. nov., a novel planctomycete isolated from the biofilm of the red alga Chondrus crispus. Syst Appl Microbiol 43:126083

Vollmers J, Frentrup M, Rast P, Jogler C, Kaster AK (2017) Untangling genomes of novel planctomycetal and verrucomicrobial species from Monterey Bay kelp forest metagenomes by refined binning. Front Microbiol 8:472

Wagner M, Horn M (2006) The Planctomycetes, Verrucomicrobia, Chlamydiae and sister phyla comprise a superphylum with biotechnological and medical relevance. Curr Opin Biotechnol 17:241-249

Wang J, Ruan C-J, Song L, Li A, Zhu Y-X, Zheng X-W, Wang L, Lu Z-J, Huang Y, Du W, Zhou Y, Huang L, Dai X (2020) Gimesia benthica sp. nov., a planctomycete isolated from a deep-sea water sample of the Northwest Indian Ocean. Int J Syst Evol Microbiol 70:4384-4389

Wiegand S, Jogler M, Jogler C (2018) On the maverick Planctomycetes. FEMS Microbiol Rev 42:739-760

Wiegand S, Jogler M, Boedeker C, Pinto D, Vollmers J, RivasMarin E, Kohn T, Peeters SH, Heuer A, Rast P, Oberbeckmann S, Bunk B, Jeske O, Meyerdierks A, Storesund JE, Kallscheuer N, Lucker S, Lage OM, Pohl T, Merkel BJ, Hornburger P, Muller RW, Brummer F, Labrenz M, Spormann AM, Op den Camp HJM, Overmann J, Amann R, Jetten MSM, Mascher T, Medema MH, Devos DP, Kaster AK, Ovreas L, Rohde M, Galperin MY, Jogler C (2020) Cultivation and functional characterization of 79 planctomycetes uncovers their unique biology. Nat Microbiol 5:126-140

Will SE, Henke P, Boedeker C, Huang S, Brinkmann H, Rohde M, Jarek M, Friedl T, Seufert S, Schumacher M (2018) Day and night: metabolic profiles and evolutionary relationships of six axenic non-marine cyanobacteria. Genome Biol Evol 11:270-294

Yarza P, Yilmaz P, Pruesse E, Glöckner FO, Ludwig W, Schleifer KH, Whitman WB, Euzeby J, Amann R, RosselloMora R (2014) Uniting the classification of cultured and uncultured bacteria and archaea using 16S rRNA gene sequences. Nat Rev Microbiol 12:635-645

Publisher's Note Springer Nature remains neutral with regard to jurisdictional claims in published maps and institutional affiliations. 